\title{
Article \\ Antioxidant, Antibacterial and Dyeing Potential of Crude Pigment Extract of Gonatophragmium triuniae and Its Chemical Characterization
}

\author{
Ajay C. Lagashetti ${ }^{1,2}$, Sanjay K. Singh ${ }^{1,2, * \mathbb{C}}$, Laurent Dufossé ${ }^{3, *} \mathbb{D}$, Pratibha Srivastava ${ }^{2,4}$ and Paras N. Singh ${ }^{1,2}$ \\ 1 National Fungal Culture Collection of India (NFCCI), Biodiversity and Palaeobiology Group, \\ MACS' Agharkar Research Institute, G.G. Agarkar Road, Pune 411004, India; \\ lagashettiajay@gmail.com (A.C.L.); pnsingh@aripune.org (P.N.S.) \\ 2 Faculty of Science, Savitribai Phule Pune University, Pune 411007, India \\ 3 CHEMBIOPRO Chimie et Biotechnologie des Produits Naturels, ESIROI Département Agroalimentaire, \\ Université de la Réunion, F-97490 Sainte-Clotilde, Ile de La Réunion, France \\ 4 Bioprospecting Group, MACS' Agharkar Research Institute, G.G. Agarkar Road, Pune 411004, India; \\ psrivastava@aripune.org \\ * Correspondence: sksingh@aripune.org (S.K.S.); laurent.dufosse@univ-reunion.fr (L.D.); \\ Tel.: +91-20-25325103 (S.K.S.); +33-66-8731906 (L.D.)
}

check for updates

Citation: Lagashetti, A.C.; Singh, S.K.; Dufossé, L.; Srivastava, P.; Singh, P.N. Antioxidant, Antibacterial and Dyeing Potential of Crude Pigment Extract of Gonatophragmium triuniae and Its Chemical Characterization. Molecules 2022, 27, 393. https:// doi.org/10.3390/molecules27020393

Academic Editor: Jacqueline

Aparecida Takahashi

Received: 13 December 2021

Accepted: 5 January 2022

Published: 8 January 2022

Publisher's Note: MDPI stays neutral with regard to jurisdictional claims in published maps and institutional affiliations.

Copyright: (c) 2022 by the authors Licensee MDPI, Basel, Switzerland. This article is an open access article distributed under the terms and conditions of the Creative Commons Attribution (CC BY) license (https:// creativecommons.org/licenses/by/ $4.0 /)$.

\begin{abstract}
Filamentous fungi synthesize natural products as an ecological function. In this study, an interesting indigenous fungus producing orange pigment exogenously was investigated in detail as it possesses additional attributes along with colouring properties. An interesting fungus was isolated from a dicot plant, Maytenus rothiana. After a detailed study, the fungal isolate turned out to be a species of Gonatophragmium belonging to the family Acrospermaceae. Based on the morphological, cultural, and sequence-based phylogenetic analysis, the identity of this fungus was confirmed as Gonatophragmium triuniae. Although this fungus grows moderately, it produces good amounts of pigment on an agar medium. The fermented crude extract isolated from G. triuniae has shown antioxidant activity with an $\mathrm{IC}_{50}$ value of $0.99 \mathrm{mg} / \mathrm{mL}$ and antibacterial activity against Grampositive bacteria (with MIC of $3.91 \mu \mathrm{g} / \mathrm{mL}$ against Bacillus subtilis, and $15.6 \mu \mathrm{g} / \mathrm{mL}$ and $31.25 \mu \mathrm{g} / \mathrm{mL}$ for Staphylococcus aureus and Micrococcus luteus, respectively). Dyeing of cotton fabric mordanted with $\mathrm{FeSO}_{4}$ using crude pigment was found to be satisfactory based on visual observation, suggesting its possible use in the textile industry. The orange pigment was purified from the crude extract by preparative HP-TLC. In addition, UV-Vis, FTIR, HRMS and NMR $\left({ }^{1} \mathrm{H}\right.$ NMR, $\left.{ }^{13} \mathrm{C} \mathrm{NMR}\right)$, COSY, and DEPT analyses revealed the orange pigment to be "1,2-dimethoxy-3H-phenoxazin-3-one" $\left(\mathrm{C}_{14} \mathrm{H}_{11} \mathrm{NO}_{4}, m / z 257\right)$. To our understanding, the present study is the first comprehensive report on Gonatophragmium triuniae as a potential pigment producer, reporting "1,2-dimethoxy-3H-phenoxazin3-one" as the main pigment from the crude hexane extract. Moreover, this is the first study reporting antioxidant, antibacterial, and dyeing potential of crude extract of G. triuniae, suggesting possible potential applications of pigments and other bioactive secondary metabolites of the G. triuniae in textile and pharmaceutical industry.
\end{abstract}

Keywords: Gonatophragmium triuniae; pigments; bioactivity; dyeing; chemical characterization

\section{Introduction}

Ascomycetous filamentous fungi are known to produce bio-pigments extensively used as colourants, additives, colour intensifiers, antimicrobial, antioxidants, etc., in different industries such as food, beverages, cosmetics, textiles, and pharmaceuticals [1-3]. Natural pigments/colours are gaining increased attention currently because of the adverse effects of synthetic colours on humans and the environment. Most of the synthetic colours have been found to be toxic, allergic, and carcinogenic to human beings, and hazardous to the environment [4-6]. This has increased the need for safe, natural, eco-friendly pigments as 
an alternative to synthetic pigments. Increasing demand for natural pigments necessitates a greater need to explore colours or pigments from safe, natural sources, especially from microbes (bacteria, fungi, algae, lichens, and actinomycetes).

Fungi are currently emerging as a better and excellent source of natural pigments. Many researchers have reported fungi of different taxonomic groups exhibiting the production of pigments of diverse chemicals classes such as carotenoids, flavins, ubiquinones, anthraquinones, quinines, phenazines, etc. [1,7-10]. Due to the additional attributes of these "mycopigments" such as antimicrobial, anticancer, antioxidant, cytotoxicity, activity, etc. in addition to colouring property, they are being extensively used for a wide range of applications in food, textiles, medicines, paints, cosmetics, and electronics [8,9]. Some fungal pigments such as azaphilones, astaxanthin, Arpink Red, riboflavin, $\beta$-carotene isolated from Monascus, Xanthophyllomyces dendrorhous, Penicillium oxalicum, Ashbya gossypii, and Blakeslea trispora, respectively, are already in the market for their commercial and industrial applications [11]. Numerous studies have reported the dyeing potential of fungal pigments and suggested their possible use in the textile industry for dyeing different types of textile fabrics like cotton, silk, wool, etc. [7,8,12,13].

Literature indicates that extensive studies have been done worldwide on production, optimization, and applications of pigments from common ascomycetous fungi like Monascus, Talaromyces, Aspergillus, Penicillium, Fusarium, etc. [8,9]. Besides these conventional ones, several other genera, such as Epicoccum, Trichoderma, Alternaria, Chaetomium, etc., are reported to have good pigment production potential [7,14-18]; however, several genera of filamentous ascomycetes are still unknown and unexplored for their pigment production potential and exploitations. These unexplored fungi might prove to be a hidden treasure of novel bio-active pigments having a variety of applications.

Taking this view into account, we have planned the present research in which we have isolated an uncommon fungus, Gonatophragmium triuniae, from infected leaves of the Maytenus rothiana, a plant endemic to central Maharashtra (Western Ghats). Interestingly, it was found that this rare fungus produces a very good extracellular orange pigment on solid media [potato dextrose agar medium (PDA)] as well as in liquid media [potato dextrose (PD) broth]. For the characterization of pigment, pure culture of G. triuniae was subjected to flask level fermentation in PD broth, and pigments were extracted from the culture filtrate using Hexane and dried. The dried Hexane extract was then examined for its antimicrobial and antioxidant properties and also assessed for its dyeing potential on cotton fabric using two mordants (Alum \& $\mathrm{FeSO}_{4}$ ). Finally, by preparative thin-layer chromatography (TLC), we purified an orange pigment from the crude pigment extract and identified it as "1,2-dimethoxy-3H-phenoxazin-3-one" based on ultra-violet (UV); Fourier transform infrared (FTIR); high-resolution mass (HRMS) spectroscopy; and ${ }^{1} \mathrm{H} \&{ }^{13} \mathrm{C} N M R$, COSY, and DEPT analysis.

Several natural and synthetic phenoxazines are well known for their bioactivity and dyeing properties. These phenoxazines were found to exhibit antioxidant, antibacterial, anti-proliferative, and anti-tumoral activities [19]. 3H-phenoxazin-3-one and its derivatives exhibiting numerous biological activities (antimicrobial, anticancer, antitumor, antiviral, antitubercular, anticoccidial, antineoplastic, phytotoxic, and cell growth-stimulating) have been reported from different microorganisms such as actinomycetes, lichens, and fungi [20]. Phenoxazine class of pigments such as Phenoxazone, Pycnosanguin, Cinnabarine, $\mathrm{O}$-acetyl cinnabarine, 2-Amino-9-formylphenoxazone-1-carbonic acid, and 9-Hydroxymethyl-2methylaminophenoxazone-1-carbonic acid methyl ester have been described from the fungus Pycnoporus sanguineus [21]. Similarly, Chandrananimycins A-C belonging to class $3 H$-phenoxazin-3-one, exhibiting antitumor activity against colon cancer (CCL HT29); breast cancer (LCL H460, CNCL SF268, MACL MCF-7); lung cancer (LXFA 526L, LXFL 529L); melanoma (MEXF 514L); and kidney tumor cells (PRCL PC3M, RXF 631L) has also been reported from Actinomadura sp. [22,23]. One of the recent studies evaluated the antibacterial activity of the synthesized derivatives of $3 \mathrm{H}$-phenoxazin-3-one [20]. Based on the history of Phenoxazin class of pigments, their promising bioactivity, and their 
dyeing property, we may consider present compound 1,2-dimethoxy-3H-phenoxazin-3-one isolated from G. triuniae NFCCI 4873 as a good colourant as well as a potential candidate for application in the textile and pharmaceutical industry.

\section{Results and Discussion}

\subsection{Morphological Identification}

Leaf lesions, amphigenous, necrotic spots single or irregular in concentric rings, later spots unite to form large spots. Margin: greyish-white; center: white. Colonies hypophyllus, velvety, brown. Mycelium superficial. Hyphae branched, septate, pale olivaceous to subhyaline, smooth-walled, up to $6.5 \mu \mathrm{m}$ wide. Stroma and hyphopodia are absent. Conidiophores arising from superficial hyphae, dichotomously branched, multi-septate (6-8), the width of conidiophore gradually decreasing towards the length; macronematous to mononematous, erect, smooth-walled, highly geniculate, nodose, basal half part of conidiophore olivaceous brown and subhyaline to light olivaceous towards the apex, 55-145 × 3.22-7 $\mu \mathrm{m}$. Conidiogenous cells integrated, polyblastic, terminal to intercalary, swollen towards the apex, variable in size: 10-20 $\mu \mathrm{m}$ long, bearing 10-15 loci, scars thickened and darkened, dentate or plate-like about $1 \mu \mathrm{m}$ diameter. Conidia solitary, dry, holoblastic, acropleurogenous, clavate, cylindrical, straight to slightly curved, 0-1 septate, smooth-walled, subhyaline to light olivaceous, base narrowly truncate, apex obtuse, hilum thickened and darkened, 6-15 × 2-3.6 $\mu \mathrm{m}$ (Figure 1).

Colonies on Potato Dextrose Agar (PDA), slow-growing, reach 26-29 mm diameter after 4 weeks of incubation at $25^{\circ} \mathrm{C}$; front view of colony light yellow (4A4), circular, raised, aerial mycelium slightly cottony, margin smooth. Reverse dark brown (7F8) with diffusible yellowish orange (5B8) pigment in entire media. Mycelium branched, septate, smooth-walled, with frequent anastomosis, hyaline, sterile. Colonies on Potato Carrot Agar (PCA), reach $27-28 \mathrm{~mm}$ diameter after 4 weeks at $25^{\circ} \mathrm{C}$; front view of colony grey (6C1), circular, raised, slightly cottony with margin smooth. Reverse dark brown (6F8) and with diffusible yellowish orange (5B8) pigment in entire media. Mycelium branched, septate, smooth-walled, anastomosis, hyaline, sterile (Figure 1).

\subsection{Molecular Identification and Phylogeny}

Mega Blast analysis of ITS sequence of G. triuniae NFCCI 4873 showed 100\% identity with type strain G. triuniae CBS138901; whereas LSU sequence showed 99.74\% identity with G. epiloblii CPC 34889 and 99.61\% similarity with G. triuniae CBS 138901. A phylogenetic tree was constructed based on combined ITS \& LSU rDNA sequence data of a total of 19 genetically-related isolates, which shows that our isolate was clustered with G. triuniae CBS138901 with a very strong bootstrap value of 98.4 (Figure 2). Therefore, based on combined morphological and molecular phylogenetic analysis, the present isolate was identified as G. triuniae. 


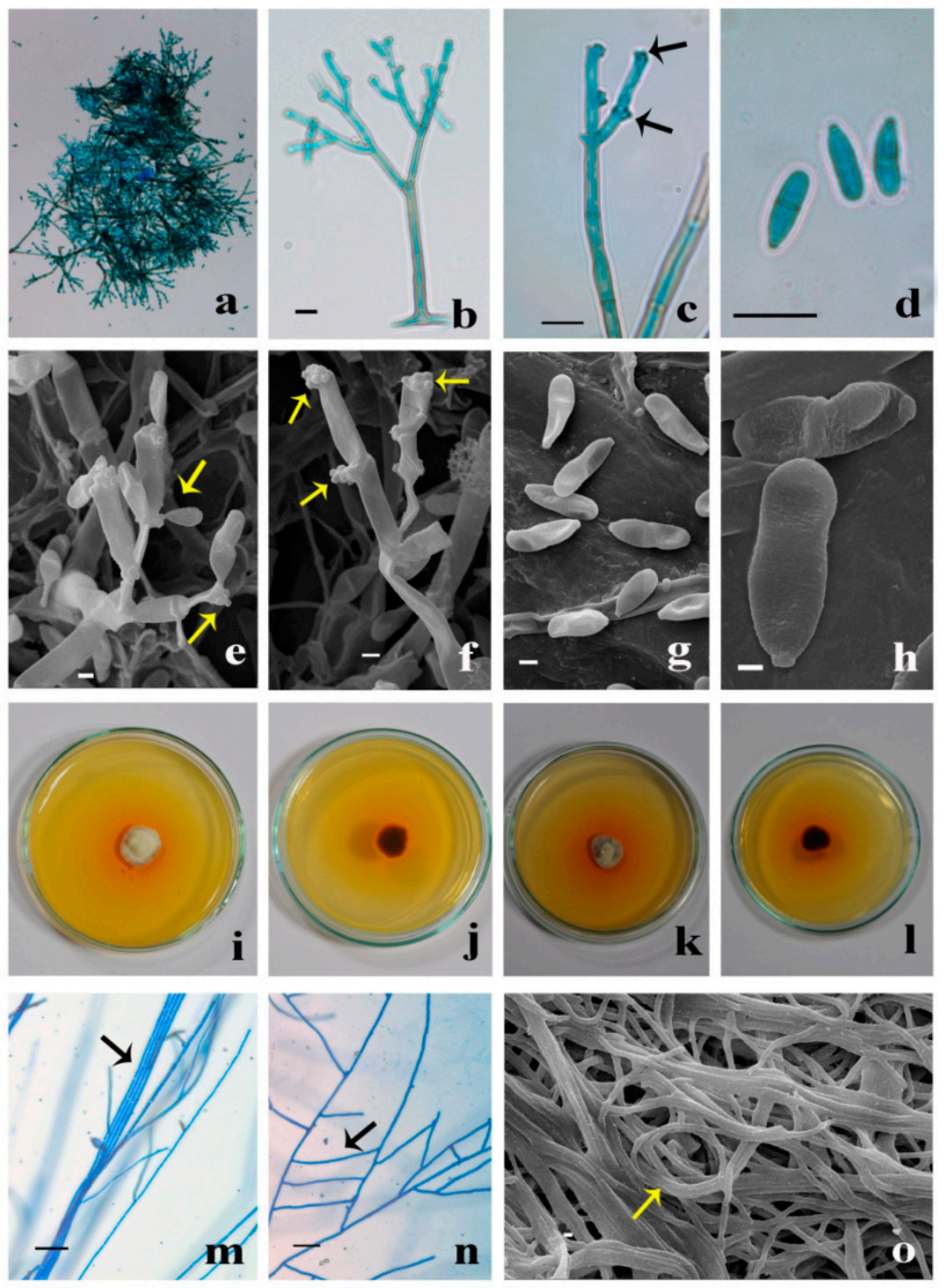

Figure 1. Gonatophragmium triuniae (NFCCI 4873): (a) Numerous conidiophores in low magnification; (b) Single dichotomously branched conidiophore; (c) Conidiophore and conidiogenous cells bearing dark scars (showing arrows); (d) Numerous conidia in high magnification; (e) SEM of conidiophores with attached conidia; (f) SEM of conidiophore bearing intercalary and terminal conidiogenous cells with dark scars (showing arrows); (g,h) SEM image of conidia; (i-1) Colonies of G. triuniae NFCCI 4873 on PDA and PCA (front and reverse view); (m,n) Hyaline sterile hyphal bundle and anastomosis in-vitro culture (showing arrows); (o) SEM of sterile hyphal bundles with coiling (showing arrow). 


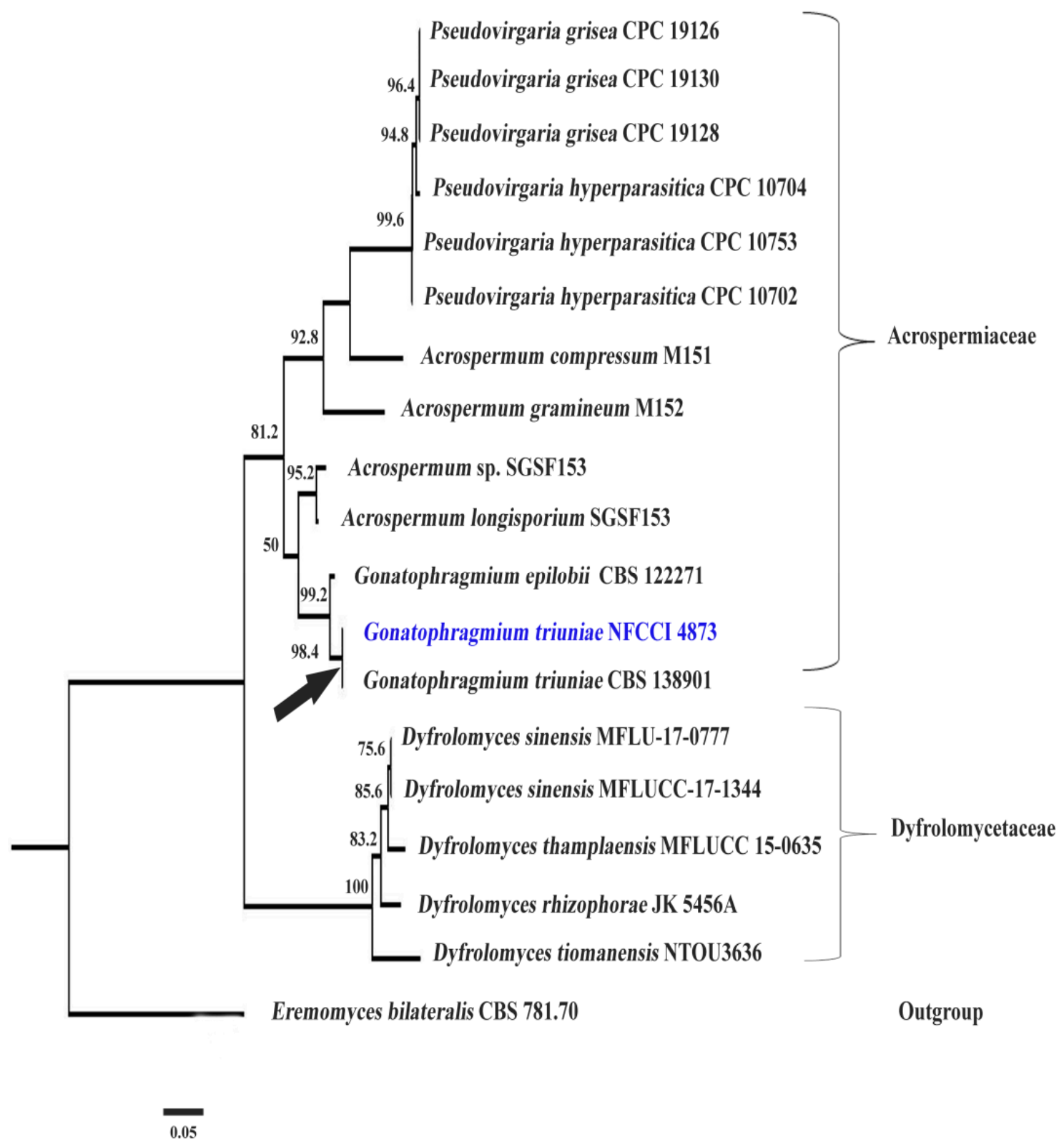

Figure 2. Phylogenetic tree of G. triuniae NFCCI 4873 based on the combined ITS \& LSU rDNA sequence data. Digits on the nodes represent the likelihood bootstrap values.

\subsection{Analysis of Pigment Production on Different Media}

After 4 weeks of incubation, G. triuniae NFCCI 4873 produced yellowish orange (5B8) pigment on potato dextrose agar (PDA), potato carrot agar (PCA), Sabouraud dextrose agar (SDA), and Czapek Yeast Extract Agar (CYA), which was completely diffused in media. In contrast, no pigment production was observed on cornmeal agar (CMA) and Czapek Dox agar (CZA) (Figure 3). 

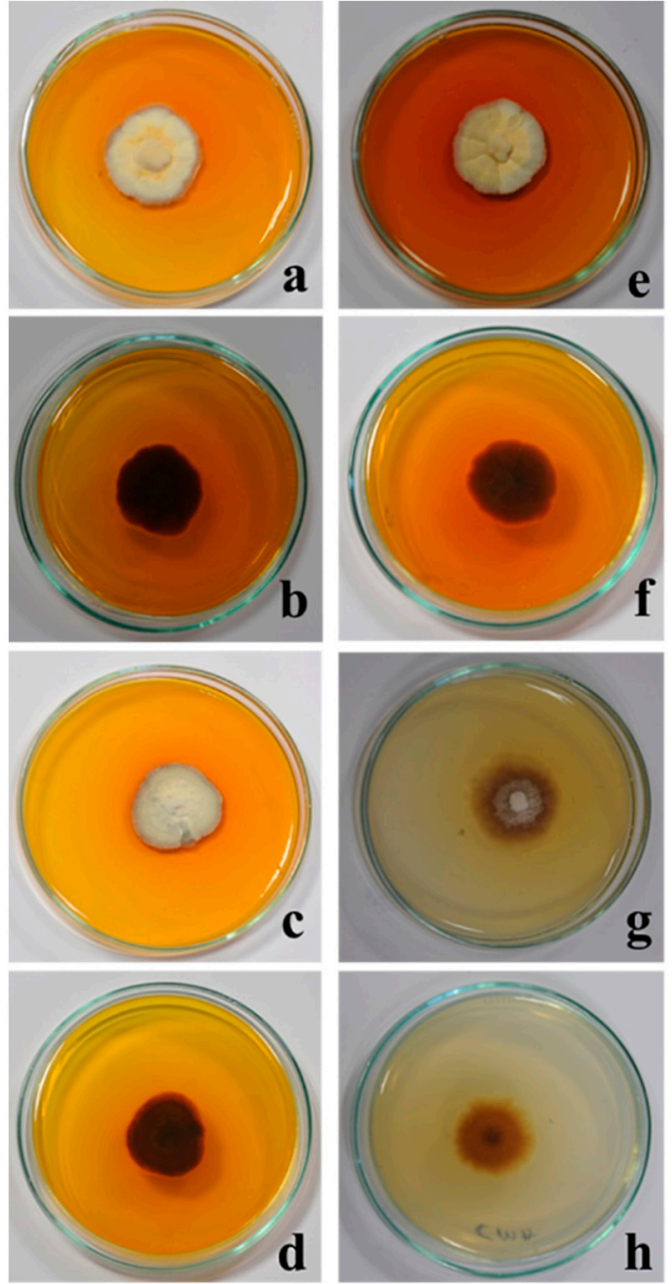

h
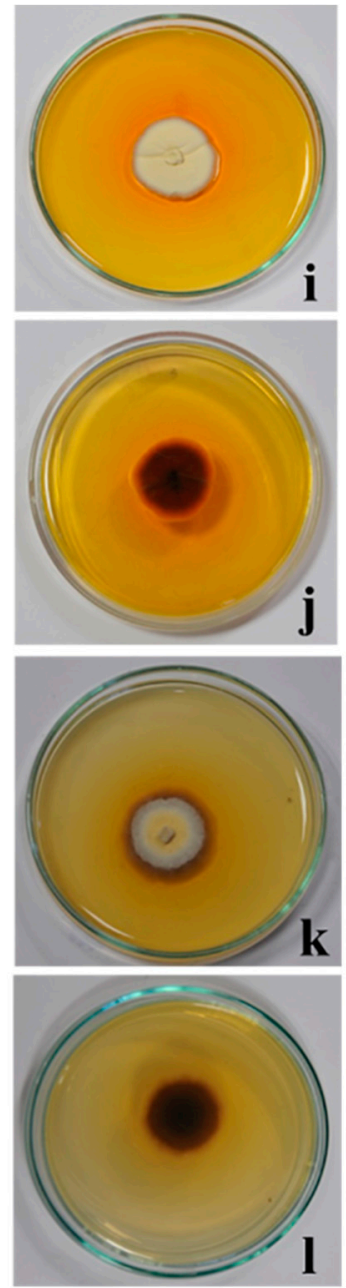

Figure 3. Studies on pigment production by G. triuniae (NFCCI 4873) on different media: $(\mathbf{a}, \mathbf{b})$ G. triuniae on PDA (front and reverse view); (c,d) G. triuniae on PCA (front and reverse view); $(\mathbf{e}, \mathbf{f})$ G. triuniae on SDA (front and reverse view); (g,h) G. triuniae on CMA (front and reverse view); $(\mathbf{I}, \mathbf{j})$ G. triuniae on CYA (front and reverse view; and (k,1) G. triuniae on CZA (front and reverse view).

\subsection{Pigment Production in Liquid Media}

G. triuniae NFCCI 4873 started pigment production earlier in PD broth of Hi-media compared to natural PD broth and natural PC broth. However, pigment production increased in natural PD broth and PC broth after 28 days of incubation compared to the PD broth of Hi-media (Figure 4). Scanning of coloured culture filtrate of G. triuniae NFCCI 4873 from three different media at a wavelength ranging from 390-760 nm shows that pigment production was higher in natural PD broth than PD broth (Hi-media) and natural PC broth (Figure 5). This clearly shows that natural potato dextrose broth supports the pigment production by G. triuniae NFCCI 4873 and suggests it as a good media for optimum pigment production. 

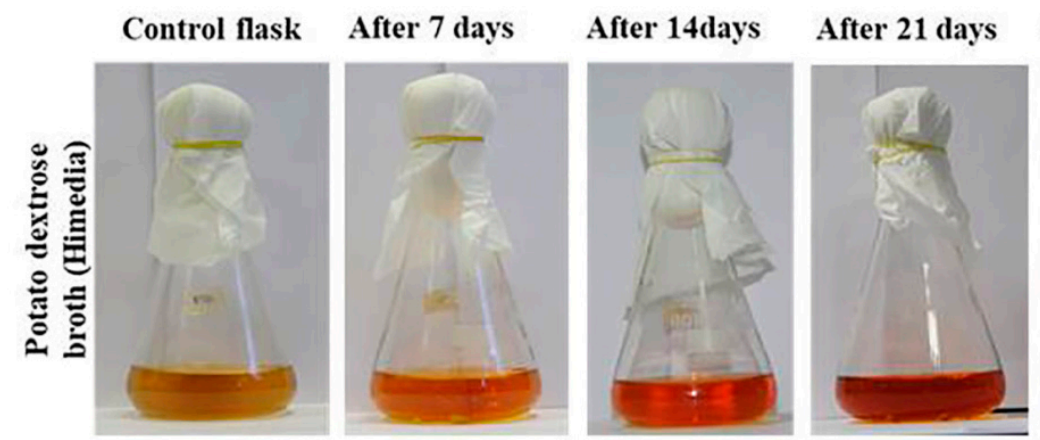

After 28 days
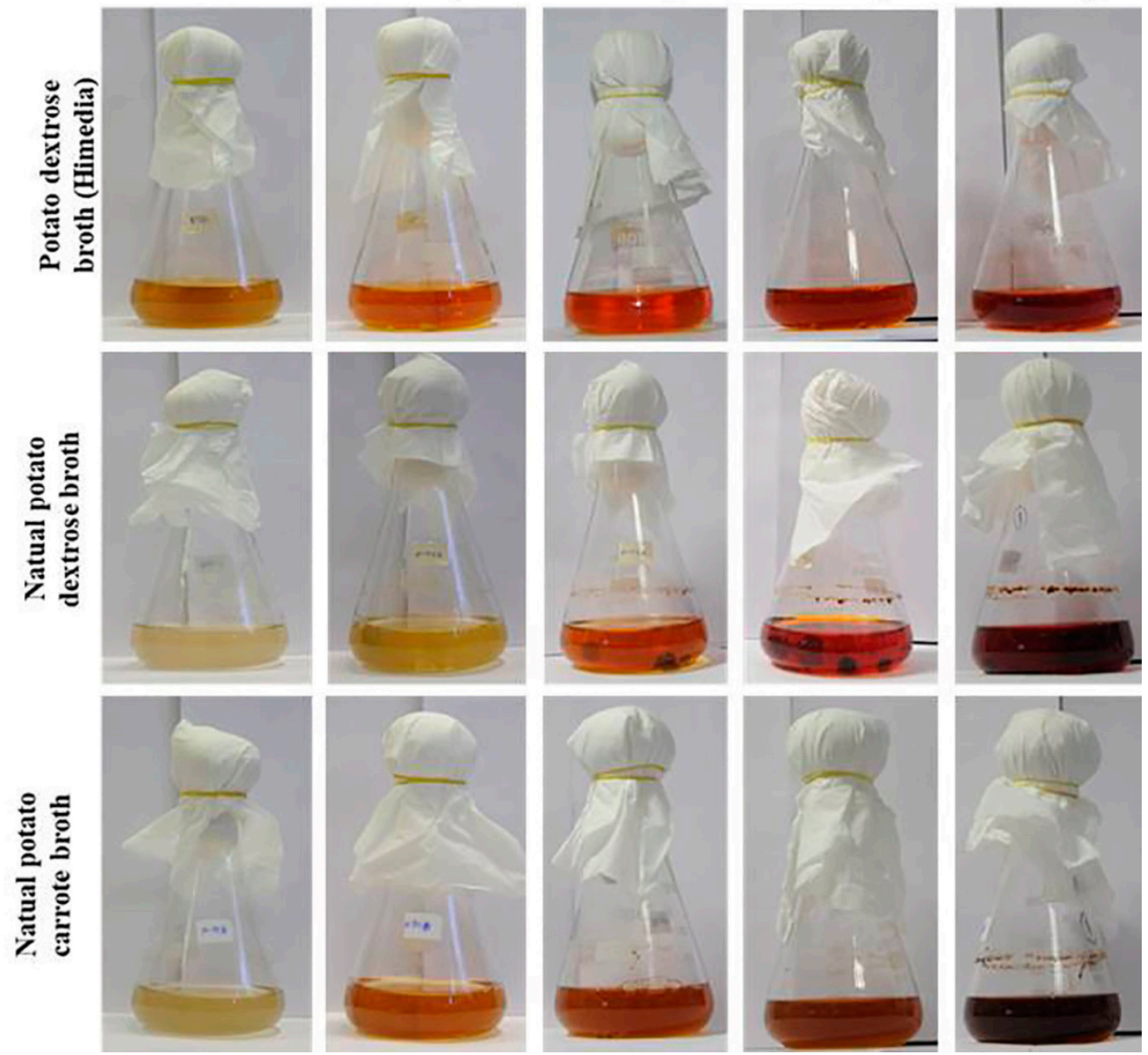

Figure 4. Analysis of pigment production by G. triuniae NFCCI 4873 in different liquid media.

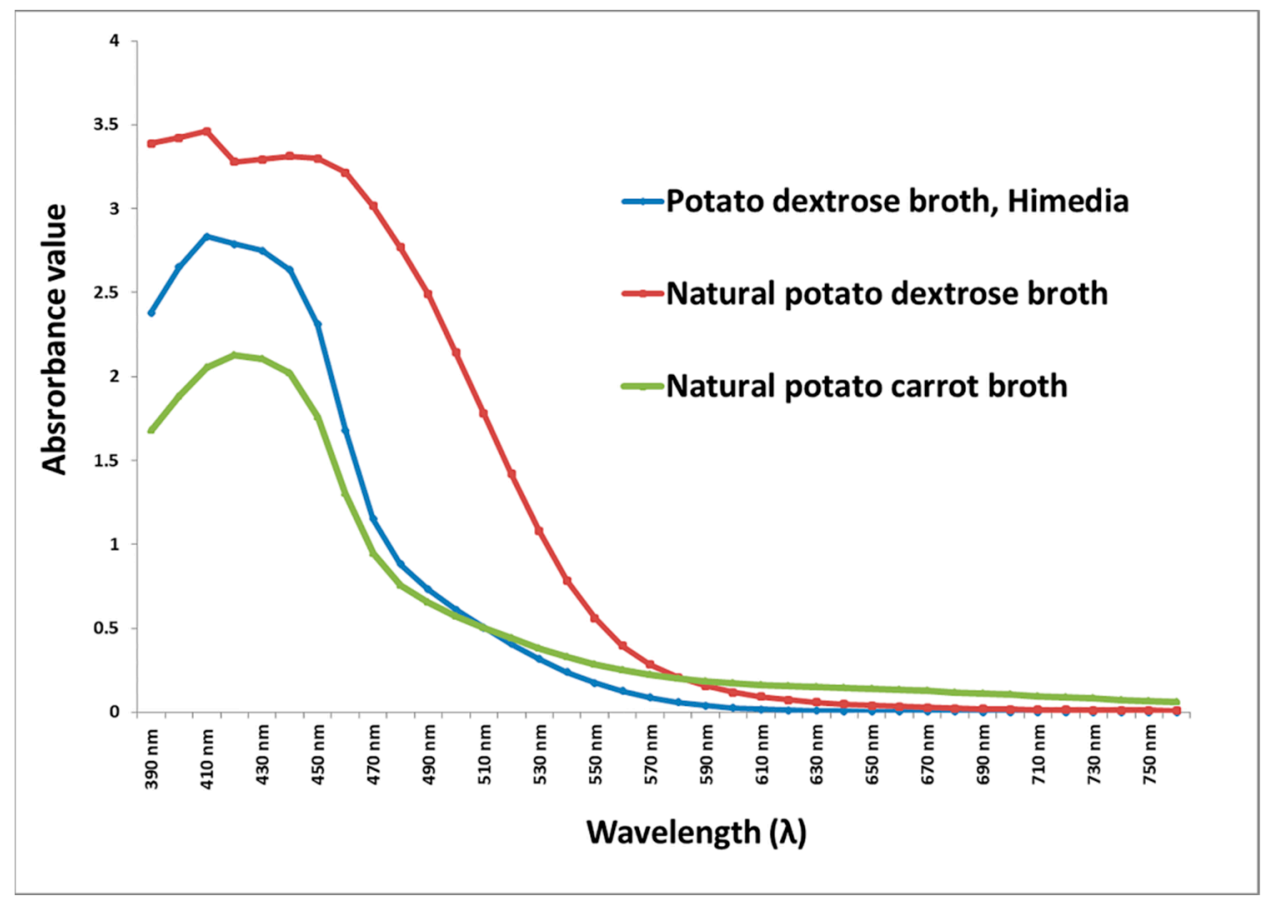

Figure 5. UV-Vis spectroscopy scanning $(390-760 \mathrm{~nm})$ of culture filtrates of different media. 


\subsection{Fermentation and Extraction of Pigments}

Upon filtration of 6-L fermentation broth of G. triuniae NFCCI 4873, approximately $4 \mathrm{~L}$ of coloured culture filtrate and $75 \mathrm{~g}$ of dry fungal biomass were obtained. Pigments from the coloured culture filtrate were extracted with Hexane, and the concentration of hexane extract in a rota evaporator under reduced pressure yielded $526.26 \mathrm{mg}$ of crude hexane extract. This dried crude hexane extract was then used for subsequent analysis, testing, and purification (Figure 6).

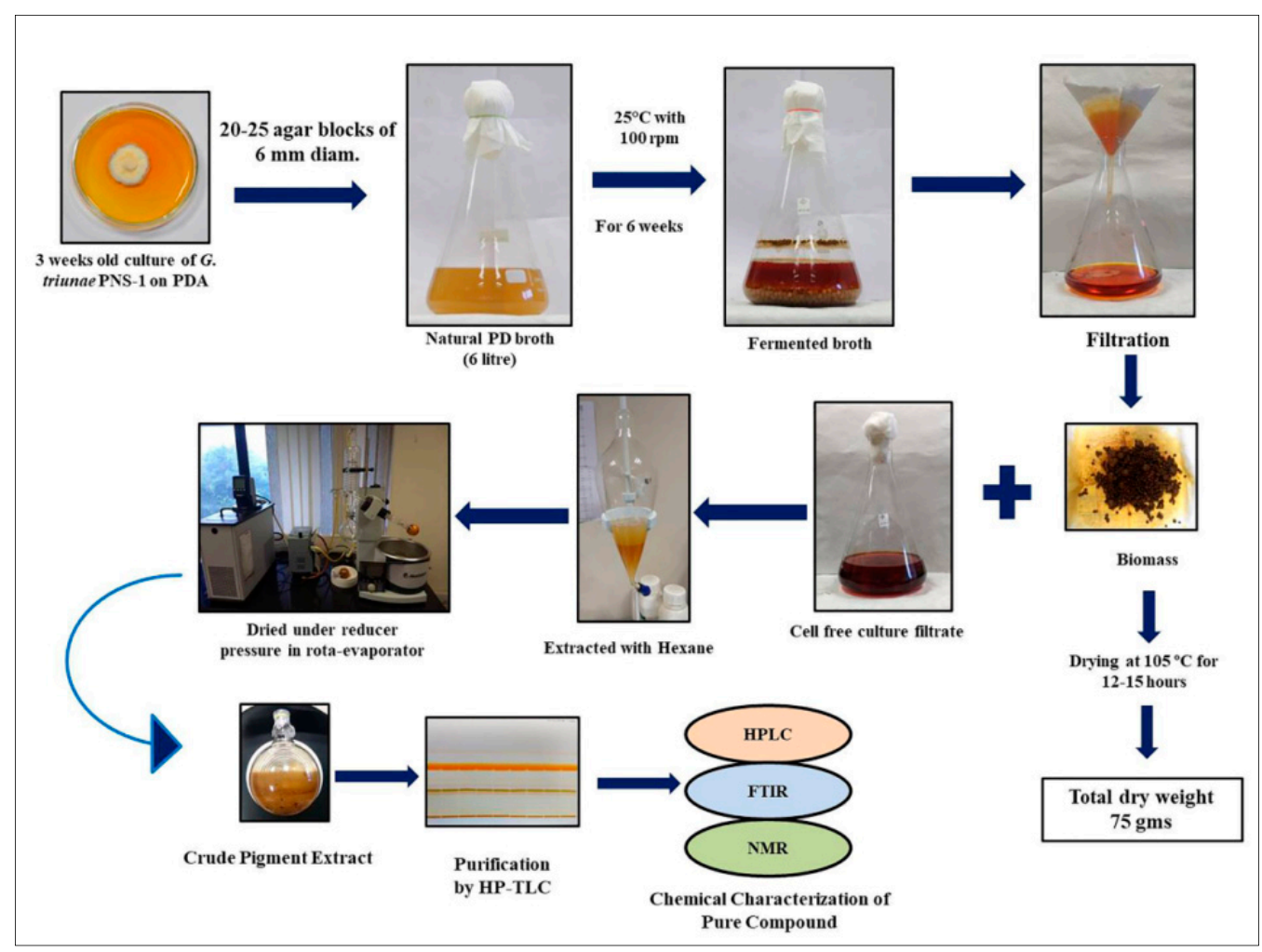

Figure 6. Schematic representation of fermentation, extraction, and purification of the compound from a pure culture of G. triuniae NFCCI 4873.

\subsection{UV-Vis Spectroscopy Analysis of Hexane Extract}

Dried hexane extract dissolved in methanol showed maximum absorption at $220 \mathrm{~nm}$ $\left(\lambda_{\max }\right)$ upon scanning at a wavelength ranging from 190-760 nm (Figure 7).

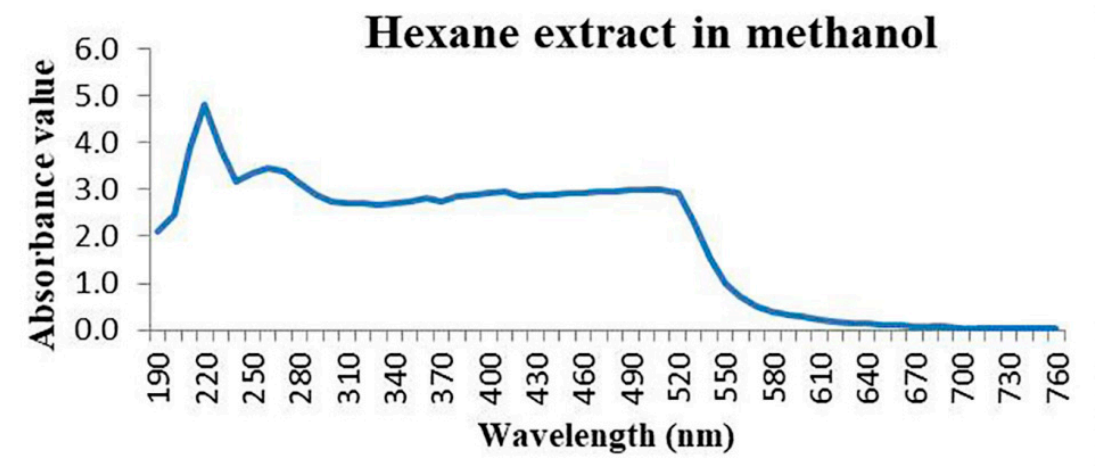

Figure 7. UV-Vis spectrum of hexane extract dissolved in methanol of G. triuniae NFCCI 4873. 


\subsection{Antagonistic Activity Testing}

The dual culture assay shows that G. triuniae NFCCI 4873 retarded the growth of fungal plant pathogens (Colletotrichum gloeosporioides, Fusarium oxysporum, and Fusarium solani). Among them, G. triuniae showed 30\% inhibition of radial growth of F. solani, followed by $23 \%$ inhibition of radial growth of $C$. gloeosporioides and $16 \%$ inhibition of radial growth of F. oxysporum. This indicates that our isolate has the potential to inhibit the growth of other fungal plant pathogens (Figure 8).
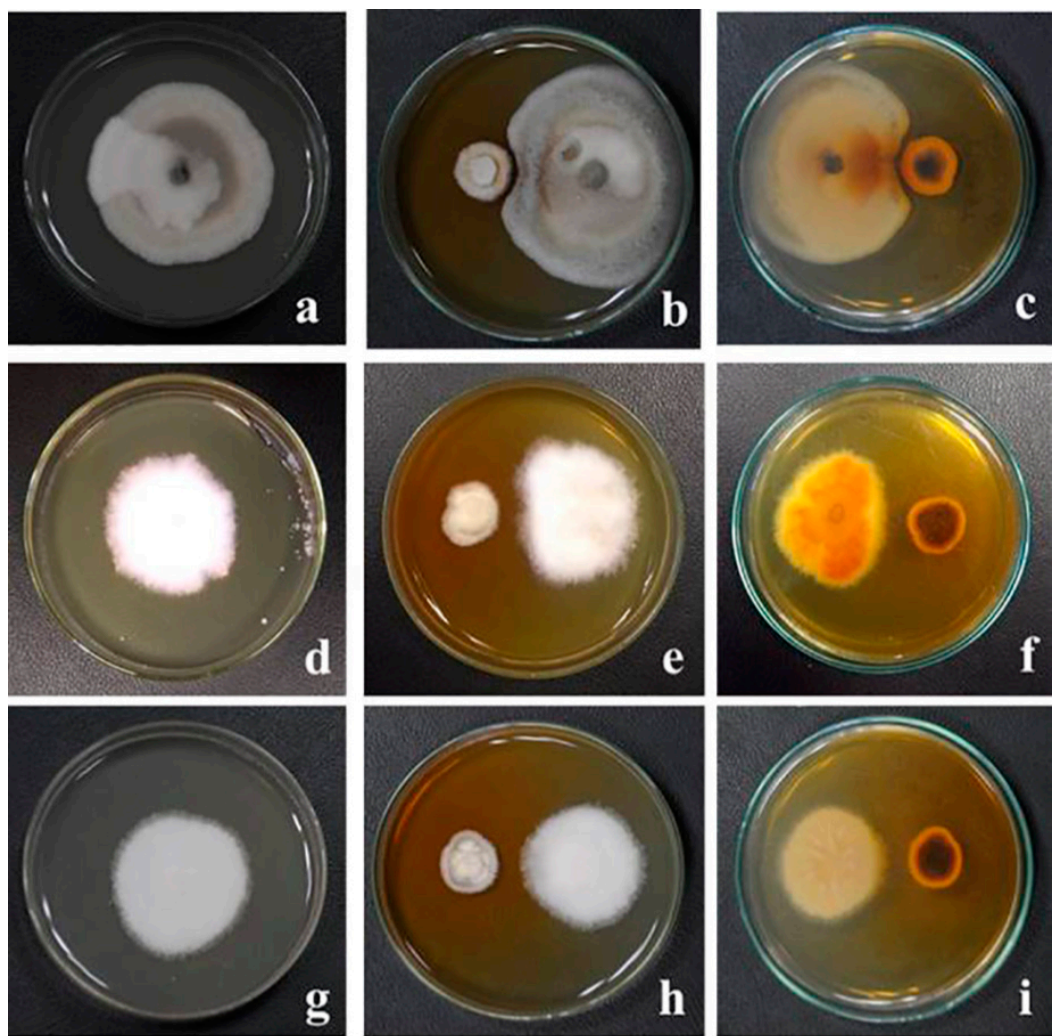

Figure 8. Antagonistic activity of G. triuniae NFCCI 4873: (a) C. gloeosporioides on PDA (control), $(\mathbf{b}, \mathbf{c})$ G. triuniae against C. gloeosporioides on PDA (front and reverse view), (d) F. oxysporum on PDA (control), (e,f) G. triuniae against F. oxysporum on PDA (front and reverse view), (g) F. solani on PDA (control), and (h,i) G. triuniae against F. oxysporum on PDA (front and reverse view).

\subsection{Antioxidant Activity Testing of G. triuniae NFCCI 4873}

From the result of in-vitro antioxidant activity, it was observed that hexane extract of G. triuniae NFCCI 4873 showed satisfactory dose-dependent DPPH radical scavenging activity with an $\mathrm{IC}_{50}$ value of $0.99 \mathrm{mg} / \mathrm{mL}$ when tested with standard ascorbic acid (IC 50 value of $0.24 \mathrm{mg} / \mathrm{mL}$ ). This suggests the promising antioxidant potential of crude hexane extract of G. triuniae NFCCI 4873 (Figure 9). 


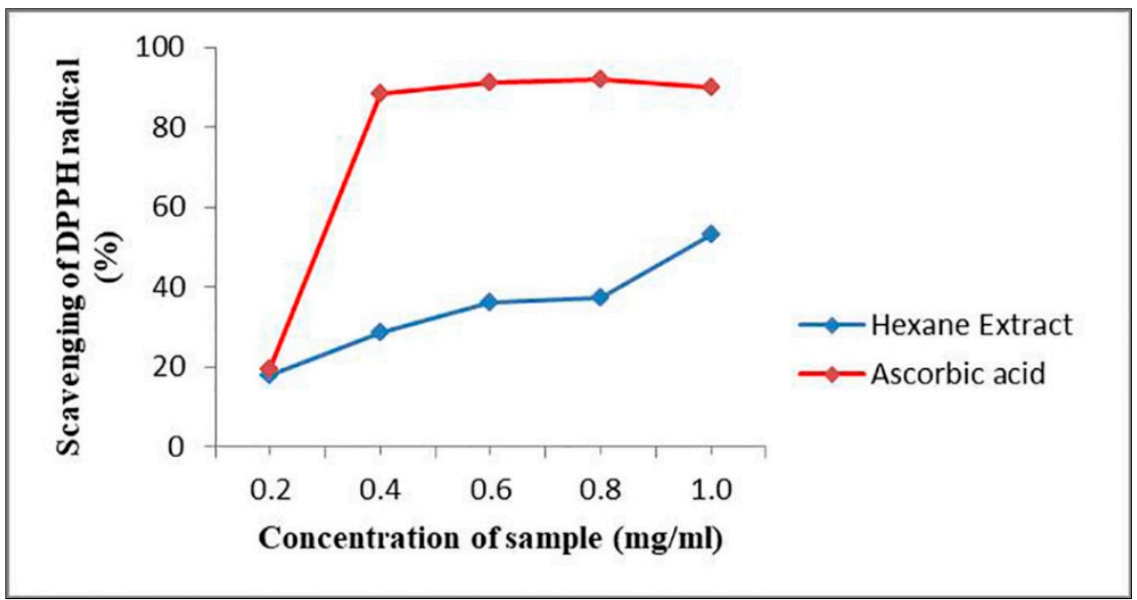

Figure 9. Scavenging effects of hexane extract of G. triuniae NFCCI 4873 on DPPH radical.

\subsection{Antimicrobial Activity Testing by Disc Diffusion}

A crude hexane extract of G. triuniae showed promising antibacterial activity in the disc diffusion assay (Figure 10). The mean diameters of the inhibition zones of test strains for the crude hexane extract of G. triuniae NFCCI 4873 are shown in Table 1. From the results of disk diffusion assay, it was observed that crude hexane extract G. triuniae NFCCI 4873 showed promising antimicrobial activity mainly against Gram-positive bacteria (B. subtilis, S. aureus, and M. luteus), displaying an average zone diameter of $17.33 \mathrm{~mm}, 18.67 \mathrm{~mm}$, and $17.33 \mathrm{~mm}$ respectively (Table 1 ). However, it showed very little activity against Gramnegative bacterium $R$. planticola with an average zone diameter of $12.33 \mathrm{~mm}$; whereas no activity was observed against $E$. coli and $P$. aeruginosa. In general, S. aureus was more sensitive to the crude hexane extract, followed by B. subtilis and M. luteus, which show similar sensitivity to the crude hexane extract. The study revealed that crude hexane extract of G. triuniae NFCCI 4873 has potential antibacterial compounds that can be used in medicines for their possible applications as an antibiotic.

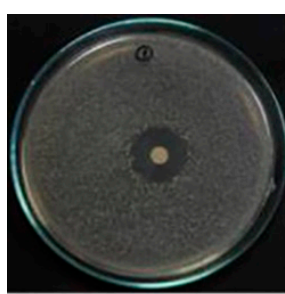

Bacillus subtilis MTCC 121

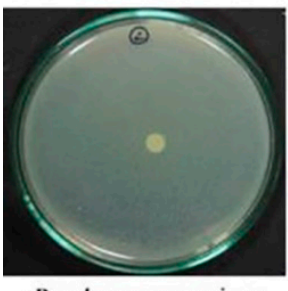

Pseudomonas aeruginose MTCC 2453

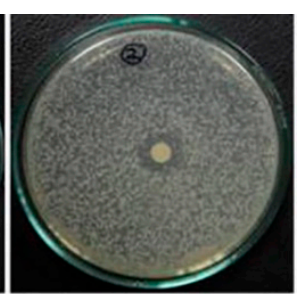

Raoultella planticola MTCC 530

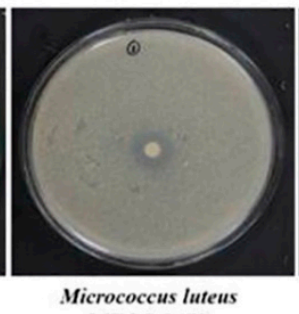

MTCC 2470

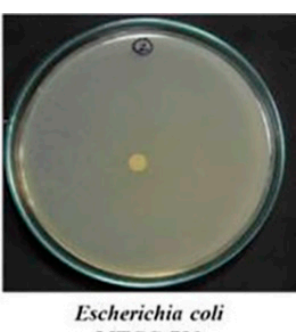

MTCC 739

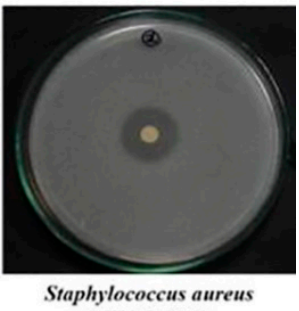

MTCC 2940

Figure 10. Antimicrobial activity of hexane extract of G. triuniae NFCCI 4873 against different test bacteria. 
Table 1. The zone of inhibition of test organisms against sample and standards with control.

\begin{tabular}{|c|c|c|c|c|c|c|}
\hline \multirow{2}{*}{ Samples } & \multicolumn{6}{|c|}{$\begin{array}{l}\text { The Diameter of the Zone of Inhibition in Millimeters } \\
\text { (Values are Average of Three Readings) }\end{array}$} \\
\hline & $\begin{array}{l}\text { E. coli MTCC } \\
739\end{array}$ & $\begin{array}{l}\text { B. subtilis } \\
\text { MTCC } 121\end{array}$ & $\begin{array}{l}\text { P. aeruginosa } \\
\text { MTCC } 2453\end{array}$ & $\begin{array}{l}\text { S. aureus } \\
\text { MTCC } 2940\end{array}$ & $\begin{array}{l}\text { R. planticola } \\
\text { MTCC } 530\end{array}$ & $\begin{array}{l}\text { M. luteus } \\
\text { MTCC } 2470\end{array}$ \\
\hline $\begin{array}{l}\text { Hexane extract } \\
\text { of G. triuniae } \\
\text { NFCCI } 4873\end{array}$ & - & $17.33 \pm 1.53$ & - & $18.67 \pm 0.58$ & $12.33 \pm 0.58$ & $17.33 \pm 1.53$ \\
\hline Streptomycin & $23.33 \pm 2.89$ & $18 \pm 0$ & $9 \pm 0$ & - & $19.67 \pm 0.58$ & $38.66 \pm 1.15$ \\
\hline Ampicillin & $18.33 \pm 2.89$ & $30.67 \pm 2.08$ & - & $14.33 \pm 1.15$ & $13.67 \pm 0.58$ & $54 \pm 0$ \\
\hline Chloramphenicol & $23.33 \pm 2.89$ & $29 \pm 1.00$ & - & $26 \pm 1.00$ & $19 \pm 1.00$ & $26.67 \pm 1.53$ \\
\hline $\begin{array}{l}\text { Ciprofloxacin } \\
\text { hydrochloride }\end{array}$ & $43.33 \pm 2.89$ & $42 \pm 1.00$ & $40 \pm 0$ & $34 \pm 1.00$ & $30.33 \pm 0.58$ & $36.67 \pm 1.53$ \\
\hline $\begin{array}{l}\text { Vancomycin } \\
\text { hydrochloride }\end{array}$ & - & $23.33 \pm 0.58$ & - & $20 \pm 1.00$ & $18.67 \pm 0.58$ & $26.67 \pm 0.58$ \\
\hline Milli-Q water & - & - & - & - & - & - \\
\hline Methanol & - & - & - & - & - & - \\
\hline
\end{tabular}

\subsection{MIC and $M B C$ of Crude Pigment}

The MIC of the crude hexane extract was found to be $3.91 \mu \mathrm{g} / \mathrm{mL}$ against $B$. subtilis and $15.6 \mu \mathrm{g} / \mathrm{mL}$ against S. aureus; whereas it was $31.25 \mu \mathrm{g} / \mathrm{mL}$ for $M$. luteus. The results of MIC show that B. subtilis had the lowest MIC, while the highest MIC obtained was for M. luteus (Figure 11).
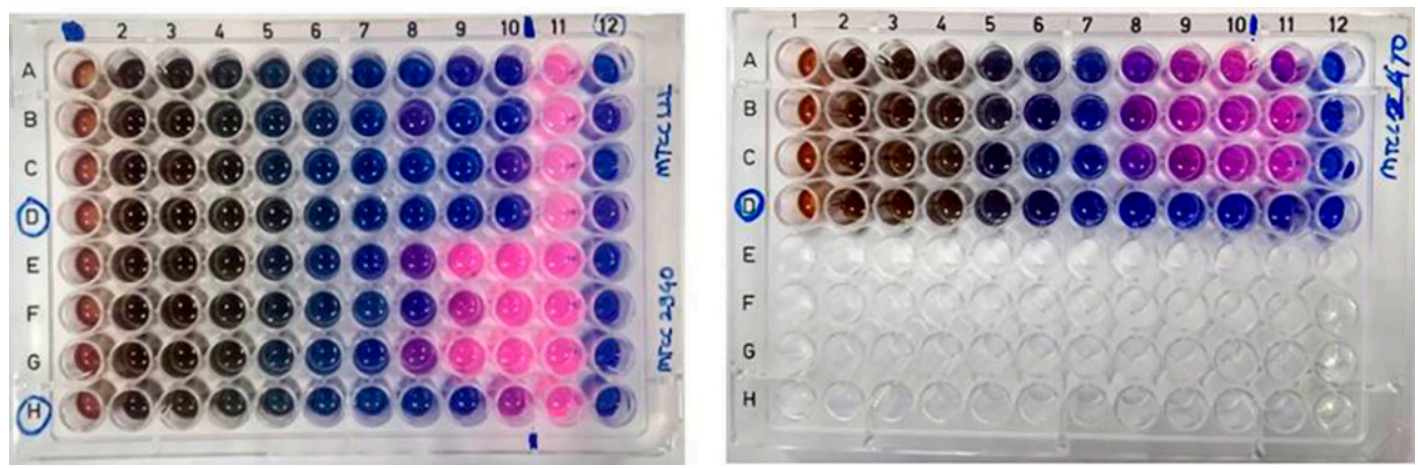

Figure 11. Microtitre plate showing MIC of crude pigment of G. triuniae NFCCI 4873.

The MBC of the crude hexane extract of G. triuniae NFCCI 4873 was found to be $1 \mathrm{mg} / \mathrm{mL}$ against $B$. subtilis MTCC 121 and $>1 \mathrm{mg} / \mathrm{mL}$ against $S$. aureus MLS 16 MTCC 2940; whereas it was $0.25 \mathrm{mg} / \mathrm{mL}$ against M. luteus MTCC 2470.

\subsection{Dyeing of Cotton Fabric}

Results of the dyeing experiment showed that cotton fabrics mordanted with different mordants $\left(\mathrm{FeSO}_{4}\right.$ and Alum) show more pigment uptake than un-mordanted fabric. Among the two mordants used, cotton fabrics mordanted with $\mathrm{FeSO}_{4}$ have shown more pigment uptake than cotton fabrics mordanted with different concentrations of Alum (Figures 12 and 13). This clearly shows that pigments of G. triuniae NFCCI 4873 have potential applications in the textile industry for dyeing different textile fabrics. Moreover, previous studies have already reported phenoxazines and their derivatives as promising textile dyes. Their intense colours and chemical nature make them excellent vat dyes. Besides this, these dyes act as good colourants for paint, ink, papers, candles, soap, and plastic materials [24]. This confirms that the main pigment "1,2-dimethoxy-3H-phenoxazin-3-one" isolated and characterized from the present study may have promising dyeing potential in the textile industry. 


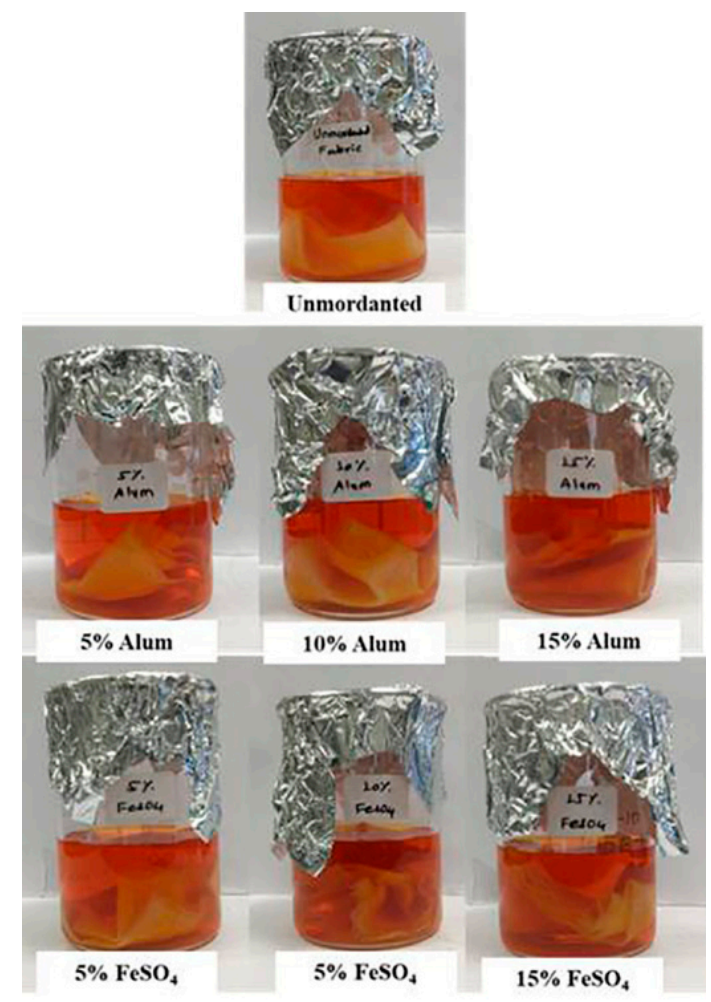

Figure 12. Dyeing of mordanted and un-mordanted cotton fabrics with crude pigment extract of G. triuniae NFCCI 4873.

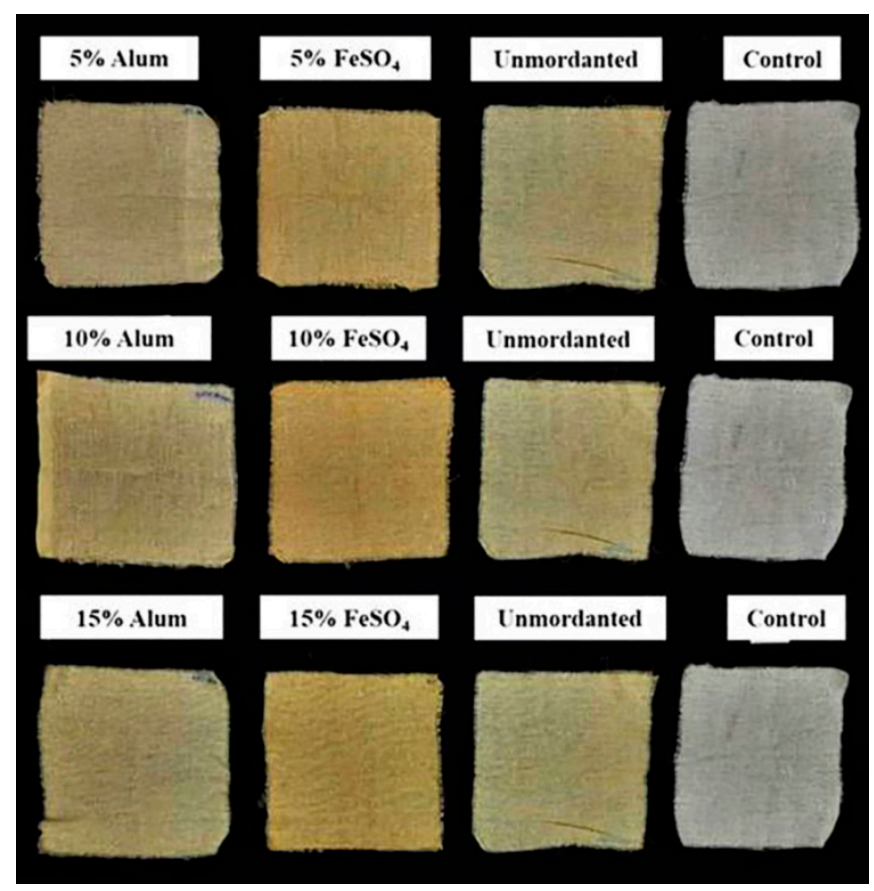

Figure 13. Cotton fabrics dyed with crude pigment extract of G. triuniae NFCCI 4873.

\subsection{GC-MS Analysis of Crude Hexane Extract}

GC-MS analysis of crude hexane extract showed the peaks along with the mass of the organic molecules present in the extract. The chromatogram showed 25 peaks corresponding to the molecules (Figure S7). The detailed data of compounds present in the extract, their molecular weight, and respective retention time is presented in Table 2. Crude hexane extract majorly showed the presence of fatty acids [n-hexadecanoic acid and 
octadecanoic acid] and their derivatives, esters (glycidyl palmitate and dibutyl phthalate), and alkanes (hexatriacontane and undecane).

Table 2. Compounds identified from hexane extract by GC-MS analysis.

\begin{tabular}{|c|c|c|c|c|}
\hline No. & Compound Name & Retention Time & Molecular Weight & $\begin{array}{c}\text { Relative Content } \\
(\%)\end{array}$ \\
\hline 1 & Undecane & 8.361 & 156 & 0.34 \\
\hline 2 & Unknown & 17.817 & 283 & 0.21 \\
\hline 3 & $\begin{array}{l}\text { 1,2-benzenedicarboxylic acid, } \\
\text { bis(2-methylpropyl) ester }\end{array}$ & 18.243 & 278 & 0.40 \\
\hline 4 & $\begin{array}{c}\text { alpha-D-Mannopyranose, 5TMS } \\
\text { derivative }\end{array}$ & 18.594 & 540 & 0.19 \\
\hline 5 & Dibutyl phthalate & 18.717 & 278 & 0.98 \\
\hline 6 & n-Hexadecanoic acid & 19.116 & 256 & 3.56 \\
\hline 7 & Dibutyl phthalate & 19.189 & 278 & 0.75 \\
\hline 8 & Phthalic acid, butyl nonyl ester & 19.386 & 348 & 0.30 \\
\hline 9 & $\begin{array}{l}\text { alpha-D-Mannopyranose, } \\
\text { 1,2,3,4,6-pentakis-O-(trimethylsilyl)- }\end{array}$ & 19.459 & 540 & 0.28 \\
\hline 10 & Hexadecanoic acid, trimethylsilyl ester & 19.854 & 328 & 1.75 \\
\hline 11 & 9-Octadecenoic acid, methyl ester, $(E)$ - & 20.401 & 296 & 0.21 \\
\hline 12 & 9-Octadecenoic acid, $(E)-$ & 20.801 & 282 & 17.62 \\
\hline 13 & Octadecanoic acid & 20.989 & 284 & 2.85 \\
\hline 14 & Unknown & 21.380 & 355 & 0.25 \\
\hline 15 & $\begin{array}{c}\text { 9-Octadecenoic acid, }(E)-\text {, TMS } \\
\text { derivative }\end{array}$ & 21.422 & 354 & 1.37 \\
\hline 16 & 9,12-Octadecadienoic acid (Z,Z)- & 21.550 & 280 & 0.47 \\
\hline 17 & Unknown & 21.655 & 327 & 1.13 \\
\hline 18 & Hexatriacontane & 21.747 & 506 & 2.71 \\
\hline 19 & Unknown & 21.820 & 383 & 0.51 \\
\hline 20 & Glycidyl palmitate & 22.149 & 312 & 0.53 \\
\hline 21 & Unknown & 22.355 & 340 & 0.65 \\
\hline 22 & Unknown & 22.697 & 355 & 28.08 \\
\hline 23 & Unknown & 22.854 & 411 & 30.35 \\
\hline 24 & Unknown & 23.126 & 397 & 2.97 \\
\hline 25 & $\begin{array}{l}\text { 9-octadecenoic acid, 1,2,3-propanetriyl } \\
\text { ester, }\end{array}$ & 23.990 & 884 & 1.56 \\
\hline
\end{tabular}

\subsection{Purification of Pigment}

Purification of crude pigment extract of G. triuniae NFCCI 4873 by preparative TLC yielded $40 \mathrm{mg}$ of purified orange compound (band 2), which was named PNS-1-OR (Figure 14). This purified pigment was used for further chemical characterization for identification. 


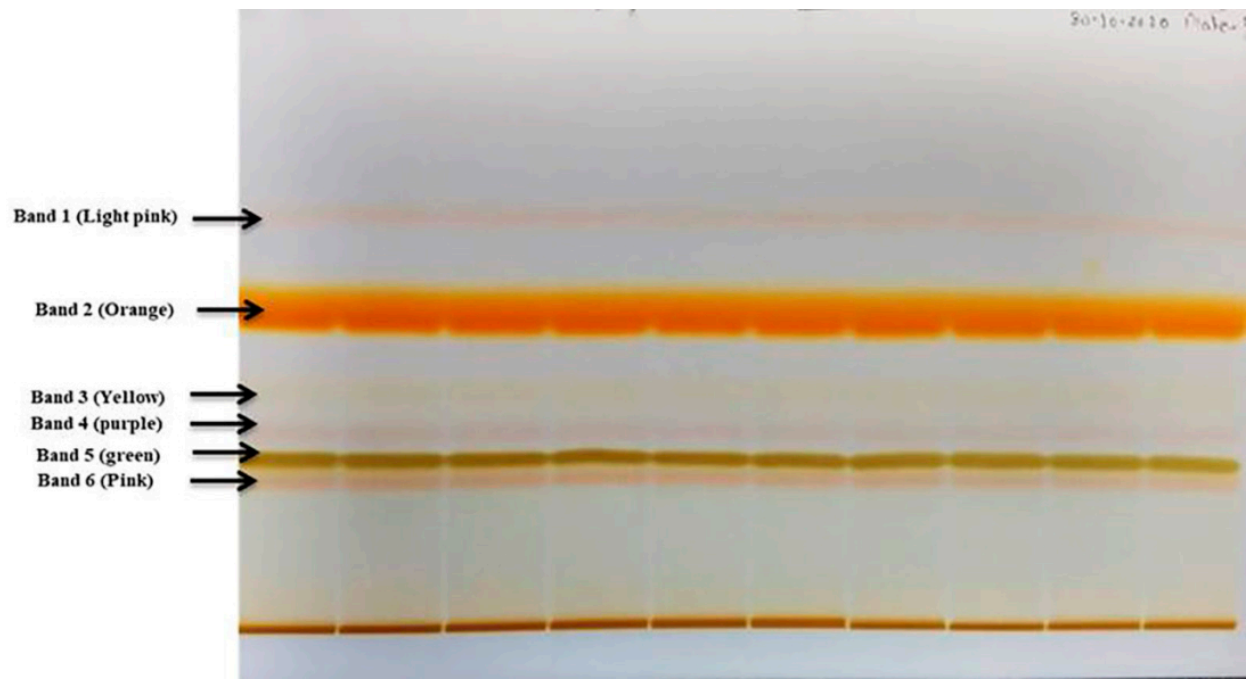

Figure 14. Separation of compounds in the crude pigment of G. triuniae NFCCI 4873 on TLC plate using HP-TLC.

\subsection{Chemical Characterization of Pure Compound (PNS-1-OR)}

HRMS spectrum of the pigment gave a sodium adduct $[\mathrm{M}+\mathrm{Na}]^{+}$at $m / z 280\left(\mathrm{C}_{14} \mathrm{H}_{11} \mathrm{NO}_{4} \mathrm{Na}\right)$ and molecular ion peak of $\mathrm{C}_{14} \mathrm{H}_{11} \mathrm{NO}_{4}$ at $m / z 258[\mathrm{M}+1]$, suggesting $\mathrm{C}_{14} \mathrm{H}_{11} \mathrm{NO}_{4}$ as its molecular formula (Figure S2). The IR spectra showed a significant carbonyl $(-\mathrm{C}=\mathrm{O})$ peak at $1647 \mathrm{~cm}^{-1},(-\mathrm{C}=\mathrm{N}) 2331 \mathrm{~cm}^{-1}$, and aromatic C-H stretching at $2943 \mathrm{~cm}^{-1}$ (Figure S1).

1,2-dimethoxy-3H-phenoxazin-3-one: This compound is orange solid. mp $145-150{ }^{\circ} \mathrm{C}$; UV $(\mathrm{MeOH}) \lambda_{\max }(\log \varepsilon) 220 \mathrm{~nm}$; IR (KBr) $v_{\max } 2943,2331,1647 \mathrm{~cm}^{-1} ;{ }^{1} \mathrm{H}$ and ${ }^{13} \mathrm{C} \mathrm{NMR}$ data, see Table 3; HR-MS m/z 258 [M+1] ${ }^{+}$(calcd. for $\mathrm{C}_{14} \mathrm{H}_{11} \mathrm{NO}_{4}, m / z 257$ ).

Table 3. The ${ }^{1} \mathrm{H}$ NMR (500 MHz, $\left.\mathrm{CDCl}_{3}\right)$ and ${ }^{13} \mathrm{C} \mathrm{NMR}\left(125 \mathrm{MHz}, \mathrm{CDCl}_{3}\right)$ spectroscopic data for 1,2-dimethoxy-3H-phenoxazin-3-one isolated from G. triuniae NFCCI 4873 along with the reported one [25].

\begin{tabular}{|c|c|c|c|c|}
\hline \multirow[t]{2}{*}{ Position } & \multicolumn{2}{|c|}{$\begin{array}{c}\text { 1,2-dimethoxy-3H-phenoxazin-3-one } \\
\text { from } \\
\text { G. triuniae NFCCI } 4873\end{array}$} & \multicolumn{2}{|c|}{$\begin{array}{c}\text { 1,2-dimethoxy-3H-phenoxazin-3- } \\
\text { one Reported from } \\
\text { A. viticola }\end{array}$} \\
\hline & $\delta_{\mathrm{C}}$ & $\delta_{\mathrm{H}}(J$ in $\mathrm{Hz})$ & $\delta_{\mathrm{C}}$ & $\delta_{\mathrm{H}}(J$ in $\mathrm{Hz})$ \\
\hline 1 & $145.2 \mathrm{C}$ & - & $145.1 \mathrm{C}$ & - \\
\hline 2 & $145.8 \mathrm{C}$ & - & $145.9 \mathrm{C}$ & - \\
\hline 3 & $181.8 \mathrm{C}=\mathrm{O}$ & - & $181.8 \mathrm{C}=\mathrm{O}$ & - \\
\hline 4 & $104.6 \mathrm{CH}$ & $6.23, \mathrm{~s}$ & $104.7 \mathrm{CH}$ & $6.23, \mathrm{~s}$ \\
\hline $4 a$ & $147.2 \mathrm{C}$ & - & $147.3 \mathrm{C}$ & - \\
\hline $5 a$ & $143.4 \mathrm{C}$ & - & $143.5 \mathrm{C}$ & - \\
\hline 6 & $115.9 \mathrm{CH}$ & $7.33, \mathrm{dd}(8.1,1.07)$ & $116.0 \mathrm{CH}$ & $7.33, \mathrm{dd}(8.2)$ \\
\hline 7 & $132.2 \mathrm{CH}$ & $7.54, \operatorname{td}(7.7,1.37)$ & $132.2 \mathrm{CH}$ & $7.53, \operatorname{td}(8.2)$ \\
\hline 8 & $125.3 \mathrm{CH}$ & $7.39, \operatorname{td}(7.71,1.37)$ & $125.3 \mathrm{CH}$ & $7.39, \operatorname{td}(8.2)$ \\
\hline 9 & $130.3 \mathrm{CH}$ & $7.92, \mathrm{dd}(7.93,1.53)$ & $130.3 \mathrm{CH}$ & $7.92, \mathrm{dd}(8.2)$ \\
\hline $9 a$ & $132.6 \mathrm{C}$ & & 132.7 C & - \\
\hline $10 a$ & $147.2 \mathrm{C}$ & & $147.8 \mathrm{C}$ & - \\
\hline 1-OMe & $62.2 \mathrm{CH}_{3}$ & $4.12, \mathrm{~s}$ & $62.3 \mathrm{CH}_{3}$ & $4.12, \mathrm{~s}$ \\
\hline 2-OMe & $61.1 \mathrm{CH}_{3}$ & $4.14, \mathrm{~s}$ & $61.2 \mathrm{CH}_{3}$ & $4.14, \mathrm{~s}$ \\
\hline
\end{tabular}

The ${ }^{1} \mathrm{H}$ NMR, ${ }^{13} \mathrm{C}$ NMR details are shown in Table 3 along with the reported data and were found in agreement with the natural product, 1,2-dimethoxy-3H-phenoxazin-3-one (Figure 15) reported from Acrospermum viticola, a leaf spot fungus of Mulberry [25]. 


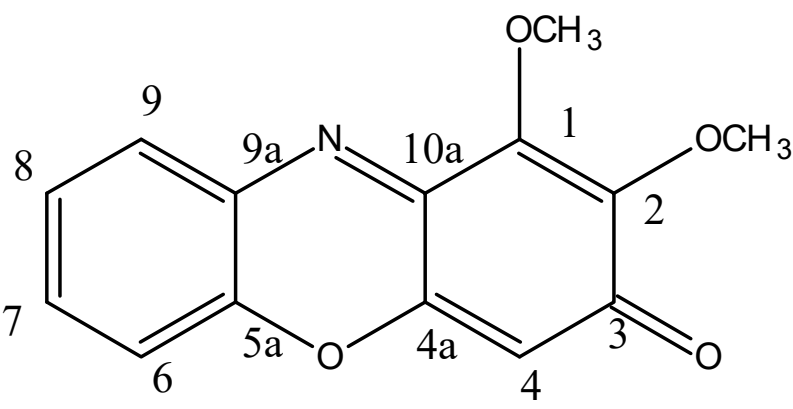

Figure 15. Natural product 1,2-dimethoxy-3H-phenoxazin-3-one.

The pigment is isolated as an orange solid: yield $(40 \mathrm{mg}, 20 \%), \mathrm{mp} 148-150{ }^{\circ} \mathrm{C}$. The ${ }^{1} \mathrm{H}$ NMR shows the distribution of protons signals between 1.0 and $8.0 \mathrm{ppm}$. Analysis of the ${ }^{1} \mathrm{H}$ NMR (Figure S3) and 2D-COSY spectra (Figure S4) revealed a sequence of 11 total hydrogens at $\delta 4.12\left(\mathrm{~s}, 3 \mathrm{H}, \mathrm{OCH}_{3}\right), 4.14\left(\mathrm{~s}, 3 \mathrm{H}, \mathrm{OCH}_{3}\right), 6.23(\mathrm{~s}, 1 \mathrm{H}, 4-\mathrm{H}), 7.33(\mathrm{dd}, 1 \mathrm{H}, J=8.1$, $1.07 \mathrm{~Hz}, 6-\mathrm{H}), 7.39(\mathrm{td}, 1 \mathrm{H}, J=7.71,1.37 \mathrm{~Hz}, 8-\mathrm{H}), 7.54(\mathrm{td}, 1 \mathrm{H}, J=7.7,1.37 \mathrm{~Hz}, 7-\mathrm{H})$, and $7.92(\mathrm{dd}, 1 \mathrm{H}, J=7.9,1.53 \mathrm{~Hz}, 9-\mathrm{H})$. The ${ }^{1} \mathrm{H}$ NMR of 1 a showed two singlets at $\delta 4.11(\mathrm{~s}, 3 \mathrm{H}$, $\left.\mathrm{OCH}_{3}\right)$ and $\delta 4.14\left(\mathrm{~s}, 3 \mathrm{H}, \mathrm{OCH}_{3}\right)$, revealing two methoxy groups at positions one and two. A singlet was observed at $\delta 6.23$ (s, 1H, C-4) next to the carbonyl group at position four. The characteristic signals for aromatic protons were observed at $\delta 7.33$ as a doublet for (dd, $J=8.09 \mathrm{~Hz}, 1 \mathrm{H}, 6-\mathrm{H})$, triplet at $\delta 7.39(\mathrm{td}, J=7.71 \mathrm{~Hz}, 1 \mathrm{H}, 8-\mathrm{H})$, triplet at $\delta 7.54(\mathrm{td}, J=7.70$, $1 \mathrm{H}, 7-\mathrm{H})$, and doublet at $\delta 7.92(\mathrm{dd}, J=7.93 \mathrm{~Hz}, 1 \mathrm{H}, 9-\mathrm{H})$. The ${ }^{1} \mathrm{H}$ COSY spectrum showed the correlation of a $6-\mathrm{H}$ proton at $\delta 7.33$ with a $7-\mathrm{H}$ proton at $\delta 7.54$ only. The $8-\mathrm{H}$ proton at $\delta 7.39$ showed a correlation with $7-\mathrm{H}$ and $9-\mathrm{H}$ at $\delta 7.54$ and 7.92, respectively. The 7-H proton at $\delta 7.54$ displayed a correlation with $6-\mathrm{H}$ and $8-\mathrm{H}$ at $\delta 7.33$ and 7.39 , respectively. The 9-H proton at 7.92 displayed a correlation with $8-\mathrm{H}$ at $\delta 7.39$.

The ${ }^{13} \mathrm{C}$ spectrum of PNS-1-OR was observed between $60 \mathrm{ppm}$ and $200 \mathrm{ppm}$. The ${ }^{13} \mathrm{C}$ NMR spectra (Figure S5) showed 14 carbons at $\delta_{\mathrm{C}} 61.1\left(\mathrm{OCH}_{3}\right), 62.2\left(\mathrm{OCH}_{3}\right), 104.6$ (C-4), 115.9 (C-6), 125.3 (C-8), 130.3 (C-9), 132.2 (C-7), 132.6 (C-9a), 143.4 (C-5a), 145.2 (C-1), 145.8 (C-2), 147.2 (C-4a, 10a), and 181.8 (C-3). The DEPT 135 analysis (Figure S6) showed the carbons that are attached to hydrogens. Therefore, peaks observed at $\delta 61.22$ and 62.26 belong to two methoxy carbon. The peak detected at $\delta 104.65$ corresponds to C-4. The displayed peaks at $\delta 115.98,125.375,130.38$, and 132.21 belong to C-6, C-8, C-9, and C-7, respectively.

The elemental analysis of $\mathrm{CHN}$ for the formula $\mathrm{C}_{14} \mathrm{H}_{11} \mathrm{NO}_{4}$ was obtained as $\mathrm{C} 64.97$, $\mathrm{H} 4.29$, and $\mathrm{N} 5.44 \%$, which was found in agreement with the calculated values C 65.37, $\mathrm{H} 4.31$, and $\mathrm{N} \mathrm{5.44 \%}$. It was confirmed that the isolated pigment is 1,2-dimethoxy-3Hphenoxazine-3-one.

\section{Materials and Methods}

\subsection{Collection and Isolation of Fungus}

Infected leaves of Maytenus rothiana were collected in sterile paper bags from the Western Ghat region (Mahabaleshwar), Maharashtra, India. Collected samples were transported to the laboratory and stored in a refrigerator at $4{ }^{\circ} \mathrm{C}$ till their processing. Collected leaves (infected with fungus) were used to isolate fungus. The lower leaf surface was found to be colonized by fungus. For the in-vitro culture of fungus, spore mass was lifted with the help of a fine needle from the infected leaf surface and suspended in $1 \mathrm{~mL}$ sterile distilled water incorporated with Tween 20. Then, with a micropipette's help, $200 \mu \mathrm{L}$ of spore suspension was spread on a $2 \%$ Neutral agar plate using a spreader, and the plate was incubated at $25{ }^{\circ} \mathrm{C}$ overnight. On the next day, the plate was observed under the CX-21 compound microscope, and germinated single spores with agar block were picked up with the help of a sterile needle and transferred on sterile potato dextrose agar (PDA) plates. Plates were incubated at $25^{\circ} \mathrm{C}$ for 7 days. The pure growing colonies were further sub-cultured on fresh PDA plates and slants. Slants were stored in a refrigerator at $4{ }^{\circ} \mathrm{C}$ till further use. 


\subsection{Morphological Identification and Deposition of Fungal Culture}

Necrotic lesions on the infected leaves were marked. Scrape mount slides were prepared in lactophenol cotton blue and observed under a microscope; based on the literature, the fungus was identified as Gonatophragmium sp. Similarly, slides were prepared in lactophenol cotton blue mount from axenic culture. Microphotographs were taken using Carl Zeiss AXIO-10 microscope, and scanning electron microscopic (SEM) images were taken using images ZEISS EVO MA 15 Scanning electron microscope at $20 \mathrm{KV}$.

A pure culture of G. triuniae was inoculated on potato dextrose agar (PDA) and potato carrot agar (PCA) to study cultural and microscopic characters. Plates were incubated at $25^{\circ} \mathrm{C}$ for 14 days, and cultural and microscopic characters were noted upon completion of incubation. Slide culture $[26,27]$ and grass leaf technique [28] were used to get the sporulation, but no sporulation was observed.

Live and pure fungal culture of G. triuniae were deposited in the National Fungal Culture Collection of India (NFCCI), Agharkar Research Institute, Pune, under the accession number NFCCI 4873. Voucher culture G. triuniae NFCCI 4873 was deposited in Ajrekar Mycological Herbarium (AMH), Agharkar Research Institute, Pune, with accession number AMH 10289.

\subsection{Molecular Identification and Phylogeny}

For the identification and authentication of fungal culture up to species level, molecular characterization was done. The fungal genomic DNA was isolated following the standard protocol [29]. Then by polymerase chain reaction (PCR), the ITS (internal transcribed spacer) and LSU (large subunit) regions of rDNA were amplified from the extracted genomic DNA using the primers ITS-4 \& ITS-5 [30] and LR-0R \& LR-7 [31], respectively. FavorPrepTM PCR Purification Kit (Favorgen, Biotech Corporation, Taiwan) was used to purify PCR products. Purified PCR products were subjected for sequencing by the BigDye Terminator v3.1 Cycle Sequencing Kit (Applied Biosystems, Waltham, MA, USA) and ABI Avant 3100 automated DNA sequencer (Applied Biosystems, USA). The manually edited sequences of ITS and LSU regions of rDNA of our fungal isolate were deposited in the nucleotide sequence database of NCBI (Gene Bank Accession Numbers: ITS- MW193329 and LSU- MW144438).

The ITS and LSU rDNA sequences of our fungal isolate were subjected to Mega BLASTn sequence homology searches. Based on the BLASTn search results, genetically related species, including genus Gonatophragmium, Acrospermum, Pseudovirgaria, and Dyfrolomyces, were chosen to construct the phylogenetic tree (Table 4). Phylogenetic analysis of G. triuniae NFCCI 4873 was performed based on a combined ITS and LSU rDNA sequence data of a total of 19 fungal cultures. The Eremomyces bilateralis CBS 781.70 was chosen as an out-group. With the help of the MUSCLE algorithm, multiple sequence alignment was performed in MEGA 7 [32]. Phylogenetic tree of G. triuniae NFCCI 4873 was constructed based on combined data of ITS \& LSU rDNA sequences in IQ-TREE multicore version 1.6.11 [33] using the Maximum Likelihood method with best-fit model TN+F+G4 Selection of the best-fit model was done using the ModelFinder employed in IQ-TREE.

\subsection{Analysis of Pigment Production on Different Media}

A pure culture of G. triuniae NFCCI 4873 was inoculated on different media such as potato dextrose agar (PDA), potato carrot agar (PCA), Sabouraud dextrose agar (SDA), Czapek Dox agar (CZA), cornmeal agar (CMA), and Czapek Yeast Extract Agar (CYA) in duplicates and incubated at $25{ }^{\circ} \mathrm{C}$ for 28 days to assess the pigment production potential. After incubation, the colour of the pigment diffused in media was recorded using the Methuen handbook of colour [34].

\subsection{Analysis of Pigment Production in Liquid Media}

The culture of $G$. triuniae was also tested for its pigment production ability in different liquid media such as potato dextrose broth (PDB, Hi-media), natural potato dextrose broth (n-PDB), and natural potato carrot broth (n-PCB). Four agar blocks of a pure culture 
of G. triuniae (6 mm diameter) from 20-days-old PDA culture plate were inoculated in a $250 \mathrm{~mL}$ Erlenmeyer flask containing $100 \mathrm{~mL}$ media (each media in the separate flask), and flasks were incubated at $25^{\circ} \mathrm{C}$ with $150 \mathrm{rpm}$. All tests were performed in duplicates. All flasks were observed intermittently after every week from the date of inoculation for pigment production, and observations were noted down. After 4 weeks of incubation, culture broths were filtered, and absorption spectrum analyses of the coloured filtrates were performed using a UV-VIS spectrophotometer (Shimadzu UV-2450). The absorbance of coloured culture filtrates was recorded in the visible light range from 390-760 nm with a $10 \mathrm{~mm}$ optical pathlength and $0.1 \mathrm{~nm}$ resolution.

Table 4. GenBank accession numbers of taxa used for phylogenetic analysis.

\begin{tabular}{|c|c|c|c|c|}
\hline \multirow{2}{*}{ Sr. No. } & \multirow{2}{*}{ Fungal Culture } & \multirow{2}{*}{ Strain } & \multicolumn{2}{|c|}{ GenBank Accession No. } \\
\hline & & & ITS & LSU \\
\hline 1 & $\begin{array}{l}\text { Gonatophragmium } \\
\text { triuniae }\end{array}$ & NFCCI 4873 & MW193329 & MW144438 \\
\hline 2 & $\begin{array}{l}\text { Gonatophragmium } \\
\text { triuniae }\end{array}$ & CBS 138901 & NR_137932 & NG_058117 \\
\hline 3 & $\begin{array}{l}\text { Gonatophragmium } \\
\text { epilobii }\end{array}$ & CBS 122271 & MH863183 & MH874728 \\
\hline 4 & Acrospermum sp. & SGSF153 & MK335823 & MK754265 \\
\hline 5 & $\begin{array}{l}\text { Acrospermum } \\
\text { longisporium }\end{array}$ & MFLU 17-2849 & - & NG_064506 \\
\hline 6 & $\begin{array}{l}\text { Acrospermum } \\
\text { gramineum }\end{array}$ & M152 & - & EU940085 \\
\hline 7 & $\begin{array}{l}\text { Acrospermum } \\
\text { compressum }\end{array}$ & M151 & - & EU940084 \\
\hline 8 & Pseudovirgaria grisea & СРС 19130 & JF957607 & JF957612 \\
\hline 9 & $\begin{array}{l}\text { Pseudovirgaria } \\
\text { hyperparasitica }\end{array}$ & СРС 10702 & EU041765 & EU041822 \\
\hline 10 & $\begin{array}{l}\text { Pseudovirgaria } \\
\text { hyperparasitica }\end{array}$ & СРС 10704 & EU041766 & EU041823 \\
\hline 11 & $\begin{array}{l}\text { Pseudovirgaria } \\
\text { hyperparasitica }\end{array}$ & СРС 10753 & EU041767 & EU041824 \\
\hline 12 & Pseudovirgaria grisea & СРC 19126 & JF957605 & JF957610 \\
\hline 13 & Pseudovirgaria grisea & СРС 19128 & JF957606 & JF957611 \\
\hline 14 & Dyfrolomyces sinensis & MFLU 17-0777 & - & NG_064507 \\
\hline 15 & Dyfrolomyces sinensis & MFLUCC 17-1344 & - & MG836699 \\
\hline 16 & $\begin{array}{l}\text { Dyfrolomyces } \\
\text { tiomanensis }\end{array}$ & NTOU3636 & - & KC692156 \\
\hline 17 & $\begin{array}{l}\text { Dyfrolomyces } \\
\text { rhizophorae }\end{array}$ & JK 5456A & - & GU479799 \\
\hline 18 & $\begin{array}{l}\text { Dyfrolomyces } \\
\text { thamplaensis }\end{array}$ & MFLUCC 15-0635 & - & KX925435 \\
\hline 19 & Eremomyces bilateralis & CBS 781.70 & NR_145364 & NG_059206 \\
\hline
\end{tabular}

\subsection{Fermentation and Extraction of Pigments}

G. triuniae culture was subjected to flask scale fermentation in a total of $6 \mathrm{~L}$ (four flasks containing $1.5 \mathrm{~L}$ of media) of natural potato dextrose broth (PD broth). Each flask was inoculated with 20-25 mycelial disks (6 mm diameter) of G. triuniae from 3-weeks-old PDA culture plate using a cork borer and incubated at $25^{\circ} \mathrm{C}$ with $100 \mathrm{rpm}$ for $4-6$ weeks. After incubation, the coloured culture broth was filtered through pre-weighed blotting paper, and culture filtrate was collected in a separate flask. Later, the pigments from the culture filtrates were extracted thrice with an equal volume of Hexane. With the help of a separating funnel, the Hexane part was separated from the culture filtrate. The separated hexane part was evaporated to dryness under reduced pressure in a rota evaporator (Heidolph, Schwabach, Germany). The resulting concentrated hexane extract was used for further experiments. 
Finally, biomass collected in a pre-weighed blotting paper was dried at $105^{\circ} \mathrm{C}$ for $12-15 \mathrm{~h}$ and weighed to measure the yield of biomass concentration [35].

\subsection{UV-VIS Spectroscopy Analysis of Hexane Extract}

UV-Visible spectroscopic analyses of the crude hexane extracts were performed using a UV-VIS spectrophotometer (Shimadzu UV-2450). The crude hexane extract was evaporated to dryness and then dissolved in methanol solvent, and absorbance was recorded in the range of $190-760 \mathrm{~nm}$ with a $0.1 \mathrm{~nm}$ resolution and $10 \mathrm{~mm}$ optical path length.

\subsection{Antagonistic Activity of G. triuniae NFCCI 4873}

Antagonistic activity of G. triuniae against three fungal pathogens (Colletotrichum gloeosporioides, Fusarium oxysporum \& Fusarium solani) was evaluated by dual culture technique [36]. Mycelial disks of $6 \mathrm{~mm}$ diameter were excised from the edge of actively growing culture of $G$. triuniae and fungal pathogens and inoculated on opposite ends of PDA plates equidistant from the periphery (each pathogen separately with test culture). For control, PDA plates were inoculated with a pathogen without test culture. Plates were then incubated at $25{ }^{\circ} \mathrm{C}$ for 14 days. Experiments were performed in duplicates. After completion of incubation, the radial growth of each fungal pathogen on PDA plates was measured, and percentage inhibition of radial growth (PIRG) of fungal pathogens was calculated relative to the control plate using the following formula:

$$
P I R G=\left[\left(R_{1}-R_{2}\right) / R_{1}\right] \times 100
$$

where $R_{1}$ is the radial growth of the fungal pathogen in the control plate, and $R_{2}$ is the radial growth of the pathogen in the presence of test culture (G. triuniae) [37].

\subsection{In-vitro Antioxidant Activity of Crude Pigment}

In-vitro antioxidant activity of hexane extracts was tested using DPPH radical scavenging method [38]. Different concentrations $(0.2,0.4,0.6,0.8$, and $1.0 \mathrm{mg} / \mathrm{mL})$ of the extract and standard solution (Ascorbic acid, Sigma, USA) were used, and for that, dilutions were prepared in methanol. For the assay, $10 \mu \mathrm{L}$ of extract or standard solution was added to $200 \mu \mathrm{L}$ of $0.1 \mathrm{mM}$ DPPH in methanol solution in a 96-well microtitre plate (Thermofisher, Waltham, MA, USA). All reactions were performed in triplicates. The plate was then incubated at $37^{\circ} \mathrm{C}$ for $30 \mathrm{~min}$ in the dark. After incubation, the absorbance of the solution in each well was measured at $490 \mathrm{~nm}$ using a Synergy HT Multi-detection microplate reader [BioTek, Winooski, VT, USA]. The percentage of radical scavenging activity of the hexane extract was calculated by the following formula:

DPPH radical scavenging activity $(\%)=[($ OD control - OD sample $) / O D$ control $] \times 100$

where OD means optical density or absorbance value. The $\mathrm{IC}_{50}$ value (concentration of sample required to scavenge $50 \%$ of free radicals) of hexane extract was determined.

\subsection{Antimicrobial Activity of Crude Hexane Extract}

Crude pigment sample was screened against a panel of test organisms, including Escherichia coli (MTCC 739), Bacillus subtilis (MTCC 121), Staphylococcus aureus MLS 16 (MTCC 2940), Pseudomonas aeruginosa (MTCC 2453), Raoultella planticola (MTCC 530), and Micrococcus luteus (MTCC 2470). The test strains were procured from Microbial Type Culture Collection (MTCC), CSIR-Institute of Microbial Technology (IMTECH), Chandigarh, India. Ciprofloxacin hydrochloride $(1 \mathrm{mg} / \mathrm{mL})$, vancomycin hydrochloride $(1 \mathrm{mg} / \mathrm{mL})$, chloramphenicol $(1 \mathrm{mg} / \mathrm{mL})$, streptomycin $(1 \mathrm{mg} / \mathrm{mL})$, and ampicillin $(1 \mathrm{mg} / \mathrm{mL})$ against bacteria, were used as positive controls. 


\subsection{Antimicrobial Activity by Disc Diffusion Method}

The antimicrobial activity of the hexane extract of G. triuniae was tested using the disk diffusion method. The standardized microbial inoculum of the test strain was prepared in a saline solution $\left(\sim 10^{6}-10^{8} \mathrm{CFU} / \mathrm{mL}\right)$ from the $24 \mathrm{~h}$ old culture plates. The culture media used was Muller-Hinton agar (MHA). A direct colony suspension method was used for the inoculum preparation in which well-isolated colonies from $24 \mathrm{~h}$ old culture plates were selected and suspended in sterile saline. Then saline suspensions of the test cultures were adjusted to achieve turbidity equivalent to a $0.5 \mathrm{McF}$ arland standard. This was done by adjusting the turbidity of the cell suspensions between 0.08 and $0.12 \mathrm{AU}$ in a UV-Vis Spectrophotometer (Shimadzu UV-2450) at $625 \mathrm{~nm}$ as recommended by CLSI guidelines. This results in a suspension with approximately 1-2 $\times 10^{8}$ colony-forming units (CFU) $/ \mathrm{mL}$ for Escherichia coli $\mathrm{ATCC}^{\circledR}$ a 25922. The resulted suspension was added in sterile molten Muller-Hinton agar $(0.5 \mathrm{~mL} / 100 \mathrm{~mL}$ of media). The final concentration of the cells in the media was $0.5-1.0 \times 10^{8} \mathrm{CFU} / \mathrm{mL}$. Then media was poured in Petri plates and allowed to solidify [39].

Sterile Whatman filter paper discs impregnated with known amounts of the test sample $(1 \mathrm{mg} / \mathrm{mL}$ of dried hexane extract dissolved in methanol) were placed on the surface of an agar plate that was inoculated with a standardized suspension of microorganisms that were to be tested. Standard antibiotics like ampicillin $(1 \mathrm{mg} / \mathrm{mL})$, ciprofloxacin hydrochloride $(1 \mathrm{mg} / \mathrm{mL})$, streptomycin $(1 \mathrm{mg} / \mathrm{mL})$, vancomycin hydrochloride $(1 \mathrm{mg} / \mathrm{mL})$, and chloramphenicol $(1 \mathrm{mg} / \mathrm{mL})$ were used as positive controls. Paper discs impregnated with only methanol and sterile water were used as negative controls. Plates were left at room temperature for $1-2 \mathrm{~h}$ for the diffusion of samples and then incubated at $37^{\circ} \mathrm{C}$ for $24 \mathrm{~h}$. After completion of incubation, all plates were observed for the zone of inhibition. The diameters of the zone of inhibition were measured in millimeters, including the disk diameter $(6 \mathrm{~mm})$. All experiments were performed in triplicates.

\subsection{Determination of Minimum Inhibitory Concentration (MIC) and Minimum Bactericidal Concentration $(M B C)$}

3.12.1. Preparation of Pigment Stock

Forty milligrams of crude pigment was dissolved in $1 \mathrm{~mL}$ of DMSO in a $2 \mathrm{~mL}$ Eppendorf tube, and a tube was mixed well. Then this $1 \mathrm{~mL}$ solution was then diluted 10 times in sterile Muller-Hinton broth (MHB), and the resultant solution was stored in the refrigerator at $4{ }^{\circ} \mathrm{C}$ until further use.

\subsubsection{Preparation of Standardized Inoculum}

The standard inoculum (0.5 McFarland) of Gram-positive bacteria (Bacillus subtilis, Staphylococcus aureus MLS 16, and Micrococcus luteus) was prepared by the direct colony suspension method as recommended by CLSI guidelines in which the $\mathrm{OD}_{625}$ value was adjusted to the equivalent of $10^{8} \mathrm{CFU} / \mathrm{mL}$ in a Shimadzu UV-2450 UV-VIS spectrophotometer [39].

\subsubsection{MIC and MBC Experiment}

The minimum inhibitory concentration (MIC) of the crude pigment extract was assessed using the standard method [39]. The MIC of the crude pigment extract was determined by the broth microdilution method in a 96-well plate as per the CLSI recommended protocol. All the wells of the microtitre plate from columns 2-11 were added with $50 \mu \mathrm{L}$ of sterile Muller-Hinton broth (MHB). The last $\left(12^{\text {th }}\right)$ column was added with $100 \mu \mathrm{L}$ of MHB as sterility control. One hundred microlitres of pigment solution $(2 \mathrm{mg} / \mathrm{mL})$ was added to the first column of the 96-well microtitre plate. Then, using a micropipette, a two-fold serial dilution was performed by transferring $50 \mu \mathrm{L}$ of the pigment solution from the first well to the succeeding well and up to the $10^{\text {th }}$ well, and the final $50 \mu \mathrm{L}$ of the solution was discarded. Standardized inoculums of bacteria were diluted 1:150 times in sterile $\mathrm{MH}$ broth to get $10^{6} \mathrm{CFU} / \mathrm{mL}$ concentrations of bacteria. Then, $50 \mu \mathrm{L}$ of microbial suspension 
$\left(10^{6}\right.$ CFUs $\left./ \mathrm{mL}\right)$ was added in each well from well 2-11; while in rows D and $\mathrm{H}$, from well $1-10$, there was no addition of bacterial suspension, which were treated as pigment control. Plates were incubated at $37^{\circ} \mathrm{C}$ for $20 \mathrm{~h}$. Each test was performed in triplicates.

After incubation at $37^{\circ} \mathrm{C}$ for $20 \mathrm{~h}, 30 \mu \mathrm{L}$ of $0.01 \%$ resazurin was added to each well, and then plates were further incubated for $2 \mathrm{~h}$ at $37{ }^{\circ} \mathrm{C}$ for the change of colour. The well-containing lowest concentration of pigment showing no colour change was considered as the MIC value.

After $20 \mathrm{~h}$ of incubation at $37^{\circ} \mathrm{C}, 10 \mu \mathrm{L}$ solution from each well (2-11) of the 96-well microtitre plate was plated on Muller-Hinton agar plate, and plates were incubated at $37^{\circ} \mathrm{C}$ for $24 \mathrm{~h}$. After completion of incubation, plates were observed for the growth of bacteria. The lowest concentrations that completely kill the bacteria and do not show growth on the MHA plate were considered minimum bactericidal concentration (MBC).

\subsection{Dyeing of Cotton with a Crude Pigment of G. triuniae NFCCI 4873}

\subsubsection{Textile Fabric}

Raw cotton fabric was collected from the local market, Pune. Cotton fabric was then cut into $10 \times 10 \mathrm{~cm}$ pieces (each weighing $1 \mathrm{gm}$ ) and used for the dyeing experiment.

\subsubsection{Scouring}

Twelve cotton fabric pieces of $10 \times 10 \mathrm{~cm}(12 \mathrm{~g})$ were pre-soaked in milli-Q water and then cooked in 2.5 L of Milli-Q water containing $20 \mathrm{~mL}$ of non-ionic detergent (Triton-X-100) for $1 \mathrm{~h}$ at $70{ }^{\circ} \mathrm{C}$ in a water bath to remove oil and dirt. Scoured cotton fabrics were then rinsed thoroughly with running water and air-dried [40].

\subsubsection{Mordanting}

Scoured cotton fabric pieces were mordanted by the pre-mordanting technique $[40,41]$. Cotton fabric pieces $(10 \times 10 \mathrm{~cm})$ were mordanted with different concentrations $(5 \%, 10 \%$, and $15 \% w / w$ of fabric) of Alum and $\mathrm{FeSO}_{4}$ for $45 \mathrm{~min}$ at $70{ }^{\circ} \mathrm{C}$ with a 1:20 material to liquid ratio (MLR). After completing mordanting, fabric pieces were rinsed in running water and finally allowed to air dry.

\subsubsection{Preparation of Dye Bath}

One hundred milligrams of dried crude pigment of G. triuniae NFCCI 4873 was redissolved in $500 \mathrm{~mL}$ of Milli-Q water using a magnetic stirrer. The resultant coloured solution was used as a dye bath for dyeing cotton fabric.

\subsubsection{Dyeing}

Unmordanted and pre-mordanted cotton fabric pieces were dyed with a crude pigment solution of $G$. triuniae NFCCI 4873 . Cotton fabric pieces $(10 \times 10 \mathrm{~cm})$ were dyed at a material to liquor ratio (MLR) of 1:50 at $70^{\circ} \mathrm{C}$ for $45 \mathrm{~min}$ in a water bath. The $\mathrm{pH}$ of the dye bath was not controlled. Dyed fabric pieces were then treated with $1 \%$ acetic acid and washed thoroughly in running water. The dyed fabric pieces were then rinsed with cold water and dried overnight in the shed [40].

\subsection{GC-MS Analysis}

The dried hexane extract was subjected to derivatization using $N$-Methyl- $N$-(trimethylsilyl) trifluoroacetamide [MSTFA] as a silylating agent. For derivatization, about $5 \mathrm{mg}$ of sample was dissolved in $100 \mu \mathrm{L}$ of pyridine in a glass vial followed by the addition of $100 \mu \mathrm{L}$ of MSTFA. The solution was mixed well, heated at $60{ }^{\circ} \mathrm{C}$ for $20 \mathrm{~min}$, and cooled to room temperature. After derivatization, the sample was subjected to gas chromatography-mass spectrometric analysis using GCMS-TQ8030 (Shimadzu, Nakagyo-ku, Kyoto, Japan). A fused silica column [RTX-5MS $(30 \mathrm{~m} \times 0.25 \mathrm{~mm} \times 0.25 \mu \mathrm{m})$ ] was used. The temperature of the column was programmed from 50 to $280^{\circ} \mathrm{C}$ at a rate of $10^{\circ} \mathrm{C} / \mathrm{min}$. The injection port temperature was set at $280^{\circ} \mathrm{C}$, and a split ratio of 1:40 was used for the analysis. Helium 
was used as the carrier gas at a flow rate of $1.0 \mathrm{~mL} / \mathrm{min}$. Electron ionization source of $70 \mathrm{eV}$ and a mass range of $m / z$ 35-800 U was used for MS detection. The resultant MS peaks in the GC-MS chromatogram were identified by comparing and matching the mass and mass fragmentation pattern with the reference mass and mass fragmentation pattern in the NIST05 MS library.

\subsection{Purification of a Compound by HP-TLC}

Two-hundred milligrams of crude pigment extract of G. triuniae NFCCI 4873 was dissolved in $4 \mathrm{~mL}$ of acetone, and compounds present in crude extract were separated on silica plates using HP-TLC (CAMAAG). Hexane:ethyl Acetate (40:60) was used as the mobile phase; thin aluminium silica plates (Merck) were used as the stationary phase. After separating compounds through HP-TLC, the orange band separated on plates was cut, and the compound attached to silica was extracted with acetone. Acetone extracts were collected in a round bottom flask and dried using a rota evaporator under reduced pressure using Heidolph rota evaporator. Finally, the weight of the dried, purified pigment was measured and recorded.

\subsection{Chemical Characterization of Purified Orange Compound (PNS-1-OR)}

The high-resolution mass spectrum (HRMS) of the pure orange pigment labeled as PNS-1-OR was recorded on a Bruker IMPACT HD. FTIR spectrum of pigment was recorded on a Shimadzu-IRAffinity-1 FTIR spectrophotometer in the frequency range $4000-400 \mathrm{~cm}^{-1}$. Pure compound was subjected to ${ }^{1} \mathrm{H}(500 \mathrm{MHz})$ and ${ }^{13} \mathrm{C}(125 \mathrm{MHz}) \mathrm{NMR}$ in Bruker $500 \mathrm{MHz}$ NMR instrument using $\mathrm{CDCl}_{3}$ as a solvent for dissolving sample and TMS as internal standard. Chemical shifts ( $\delta$-values) are given in parts per million (ppm), and the coupling constants $(J$-values) are given in hertz $(\mathrm{Hz})$.

\section{Conclusions}

Many fungi of different taxonomic groups producing a wide variety of pigments of different colours and chemical classes have been reported by researchers across the world. Among them, some fungal pigments find their application in different industries possessing promising colouring properties. The present study also reports one of the unconventional fungi, i.e., G. triuniae, showing very good pigment production potential. Moreover, this is the first experimental work reporting pigments and other secondary metabolites from the fungus G. triuniae. Based on the results of the antibacterial activity of the crude pigment extract, we conclude that the crude pigment extract shows the presence of antibiotic compounds, exhibiting antibacterial activity against Gram-positive bacteria. In addition to this, the DPPH radical scavenging activity of the crude pigment extract confirmed the presence of antioxidant compounds in the crude pigment extract. Such bioactivities (antibacterial and antioxidant) of the crude pigment extract have elevated the G. triuniae as a promising source of bioactive compounds for their possible use in the medicine and pharmaceutical industry. Besides this, the dyeing property of the crude pigment extract revealed the potential use of pigments of G. triuniae in the textile industry for dyeing different types of fabrics.

The purification of crude pigment extract of G. triuniae finally yielded into a major orange-colored phenoxazine class pigment, which was characterized and identified as 1,2-dimethoxy-3H-phenoxazin-3-one $\left(\mathrm{C}_{14} \mathrm{H}_{11} \mathrm{NO}_{4}, \mathrm{M} . \mathrm{W} .257\right)$, based on UV-Vis, FTIR, HRMS, and NMR analysis. Although this pigment was already described from fungus A. viticola, this is the first study reporting the phenoxazine class of pigment from fungus G. triuniae. Considering the previous studies describing dyeing potential and bioactivity of phenoxazines, we may finally conclude that the orange pigment "1,2-dimethoxy-3Hphenoxazin-3-one" is a promising colourant and possible bioactive compound of G. triuniae, having future applications in the textile and pharmaceutical industry. 
Supplementary Materials: FTIR (Figure S1), HR-MS (Figure S2), ${ }^{1} \mathrm{H}$ NMR (Figure S3), COSY (Figure S4), ${ }^{13} \mathrm{C}$ NMR (Figure S5), and DEPT-135 (Figure S6) spectra for compound 1,2-dimethoxy-3H-phenoxazin3-one and GC-MS chromatogram (Figure S7) of hexane extract (PDF).

Author Contributions: Conceptualization, A.C.L., S.K.S.; Formal analysis, A.C.L., P.S.; Methodology, A.C.L.; Supervision, S.K.S., L.D. and P.N.S.; Writing-original draft, A.C.L.; Writing-review \& editing, S.K.S., L.D., P.S. and P.N.S. All authors have read and agreed to the published version of the manuscript.

Funding: This research received no external funding.

Institutional Review Board Statement: Not applicable.

Informed Consent Statement: Not applicable.

Data Availability Statement: Not applicable.

Acknowledgments: We thank Prashant Dhakephalkar, MACS-Agharkar Research Institute, Pune, for providing the necessary facilities and encouragement to carry out the research work. A.C. Lagashetti acknowledges CSIR (Council of Scientific and Industrial Research), New Delhi, for granting Senior Research Fellowship (SRF), and S.P. Pune University, Pune, for granting permission to register for the Ph.D. degree. We acknowledge technical support and help by S.B. Gaikwad, N.S. Gaikwad, and S. Bagale. Laurent Dufossé deeply thanks the Conseil Régional de La Réunion, Réunion island, Indian Ocean, for continuous financial support of research activities dedicated to microbial pigments.

Conflicts of Interest: The authors declare no conflict of interest.

\section{References}

1. Rao, M.P.; Xiao, M.; Li, W.J. Fungal and Bacterial Pigments: Secondary Metabolites with Wide Applications. Front. Microbiol. 2017, 8,1113

2. Mansour, R. Natural Dyes and Pigments: Extraction and Applications. In Handbook of Renewable Materials for Coloration E Finishing; Scrivener Publishing LLC: Beverly, MA, USA, 2018; Volume 9, pp. 75-102.

3. Ranaweera, S.J.; Ampemohotti, A.A.L.T.; Arachchige, U.S. Advantages, and Considerations for the Applications of Natural Food Pigments in the Food Industry. J. Res. Technol. Eng. 2020, 1, 8-18.

4. Arora, S. Textile Dyes: Its Impact on Environment and Its Treatment. J. Bioremediation Biodegrad. 2014, 5, 1000e146. [CrossRef]

5. Ardila-Leal, L.D.; Poutou-Piñales, R.A.; Pedroza-Rodríguez, A.M.; Quevedo-Hidalgo, B.E. A Brief History of Colour, The Environmental Impact of Synthetic Dyes and Removal by Using Laccases. Molecules 2021, 26, 3813. [CrossRef] [PubMed]

6. Manzoor, J.; Sharma, M. Impact of Textile Dyes on Human Health and Environment. In Impact of Textile Dyes on Public Health and the Environment; IGI Global: Hershey, PA, USA, 2020; pp. 162-169.

7. Caro, Y.; Venkatachalam, M.; Lebeau, J.; Fouillaud, M.; Dufossé, L. Pigments and Colorants from Filamentous Fungi. In Fungal Metabolites; Merillon, J.-M., Ramawat, K.G., Eds.; Springer International Publishing: Cham, Switzerland, 2017; pp. 499-568.

8. Lagashetti, A.C.; Dufossé, L.; Singh, S.K.; Singh, P.N. Fungal Pigments and Their Prospects in Different Industries. Microorganisms 2019, 7, 604. [CrossRef]

9. Ramesh, C.; Vinithkumar, N.V.; Kirubagaran, R.; Venil, C.K.; Dufossé, L. Multifaceted Applications of Microbial Pigments: Current Knowledge, Challenges and Future Directions for Public Health Implications. Microorganisms 2019, 7, 186. [CrossRef] [PubMed]

10. Khan, A.A.; Alshabi, A.M.; Alqahtani, Y.S.; Alqahtani, A.M.; Bennur, R.S.; Shaikh, I.A.; Muddapur, U.M.; Shakeel Iqubal, S.M.; Mohammed, T.; Dawoud, A.; et al. Extraction and Identification of Fungal Pigment from Penicillium europium Using Different Spectral Studies. J. King Saud Univ.-Sci. 2021, 33, 101437. [CrossRef]

11. Dufossé, L. Microbial Production of Food Grade Pigments. Food Technol. Biotechnol. 2006, 44, 313-323.

12. Kumar, A.; Vishwakarma, H.S.; Singh, J.; Dwivedi, S.; Kumar, M. Microbial Pigments: Production and Their Applications in Various Industries. Int. J. Pharm. Chem. Biol. Sci. 2015, 5, 203-212.

13. Sajid, S.; Akbar, N. Applications of Fungal Pigments in Biotechnology. Pure Appl. Biol. 2018, 7, 922-930. [CrossRef]

14. Mapari, S.A.; Meyer, A.S.; Thrane, U. Evaluation of Epicoccum nigrum for Growth, Morphology, and Production of Natural Colorants in Liquid Media and on a Solid Rice Medium. Biotechnol. Lett. 2008, 30, 2183-2190. [CrossRef]

15. Sibero, M.T.; Triningsih, D.W.; Radjasa, O.K.; Sabdono, A.; Trianto, A. Evaluation of Antimicrobial Activity and Identification of Yellow Pigmented Marine Sponge-Associated Fungi from Teluk Awur, Jepara, Central Java. Indones. J. Biotechnol. 2016, 21, 1-11. [CrossRef]

16. Heo, Y.M.; Kim, K.; Kwon, S.L.; Na, J.; Lee, H.; Jang, S.; Kim, C.H.; Jung, J.; Kim, J.J. Investigation of Filamentous Fungi Producing Safe, Functional Water-Soluble Pigments. Mycobiology 2018, 46, 269-277. [CrossRef]

17. Wang, W.; Liao, Y.; Chen, R.; Hou, Y.; Ke, W.; Zhang, B.; Gao, M.; Shao, Z.; Chen, J.; Li, F. Chlorinated Azaphilone Pigments with Anti-microbial and Cytotoxic Activities Isolated from the Deep Sea-Derived Fungus Chaetomium sp. NA-S01-R1. Mar. Drugs 2018, 16, 61. [CrossRef] [PubMed] 
18. Kalra, R.; Conlan, X.A.; Goel, M. Fungi as A Potential Source of Pigments: Harnessing Filamentous Fungi. Front. Chem. 2020, 8, 369. [CrossRef] [PubMed]

19. Polak, J.; Wlizło, K.; Pogni, R.; Petricci, E.; Grąz, M.; Szałapata, K.; Osińska-Jaroszuk, M.; Kapral-Piotrowska, J.; PawlikowskaPawlęga, B.; Jarosz-Wilkołazka, A. Structure and Bioactive Properties of Novel Textile Dyes Synthesised by Fungal Laccase. Int. J. Mol. Sci. 2020, 21, 2052. [CrossRef] [PubMed]

20. Sudhakar, C.; Reddy, M.K.; Rajyalakshmi, K.; Raju, K.R. Antibacterial Activity of Substituted 2-Bromo-1, 4-Dimethoxy-3HPhenoxazin-3-Ones. J. Chem. Pharm. Res. 2016, 8, 571-574.

21. Achenbach, H.; Blümm, E. Investigation of the Pigments of Pycnoporus sanguineus-Pycnosanguin and New Phenoxazin-3-Ones Arch. Pharm. 1991, 324, 3-6. [CrossRef]

22. Maskey, R.P.; Li, F.; Qin, S.; Fiebig, H.H.; Laatsch, H. Chandrananimycins A approximately C: Production of Novel Anticancer Antibiotics from A Marine Actinomadura sp. Isolate M048 by Variation of Medium Composition and Growth Conditions. J. Antibiot. 2003, 56, 622-629. [CrossRef]

23. Mondal, A.; Bose, S.; Banerjee, S.; Patra, J.K.; Malik, J.; Mandal, S.K.; Kilpatrick, K.L.; Das, G.; Kerry, R.G.; Fimognari, C.; et al. Marine Cyanobacteria and Microalgae Metabolites-A Rich Source of Potential Anticancer Drugs. Mar. Drugs 2020, 18, 476. [CrossRef]

24. Onoabedje, E.A.; Okoro, U.C.; Knight, D.W. Rapid Access to New Angular Phenothiazine and Phenoxazine Dyes. J. Heterocycl. Chem. 2017, 54, 206-214. [CrossRef]

25. Kinjo, J.E.; Yokomizo, K.; Awata, Y.; Shibata, M.; Nohara, T.; Teramine, T.; Takahashi, K. Structures of Phytotoxins, AV-Toxins C, D, and E, Produced by Zonate Leaf Spot Fungus of Mulberry. Tetrahedron Lett. 1987, 28, 3697-3698. [CrossRef]

26. Riddell, R.W. Permanent Stained Mycological Preparations Obtained by Slide Culture. Mycologia 1950, 42, 265-270. [CrossRef]

27. Senanayake, I.C.; Rathnayaka, A.R.; Marasinghe, D.S.; Calabon, M.S.; Gentekaki, E.; Lee, H.B.; Hurdeal, V.G.; Pem, D.; Dissanayake, L.S.; Wijesinghe, S.N.; et al. Morphological Approaches in Studying Fungi: Collection, Examination, Isolation, Sporulation, and Preservation. Mycosphere 2020, 11, 2678-2754. [CrossRef]

28. Srinivasan, M.C.; Chidambaram, P.; Mathur, S.B.; Neergaard, P. A Simple Method for Inducing Sporulation in Seed-Borne Fungi Trans. Br. Mycol. Soc. 1971, 56, 31-35. [CrossRef]

29. Aamir, S.; Sutar, S.; Singh, S.K.; Baghela, A. A Rapid and Efficient Method of Fungal Genomic DNA Extraction, Suitable for PCR Based Molecular Methods. Plant Pathol. Quar. 2015, 5, 74-81. [CrossRef]

30. White, T.J.; Bruns, T.D.; Lee, S.; Taylor, J. Amplification and Direct Sequencing of Fungal Ribosomal RNA Genes for Phylogenetics. In PCR Protocols, A Guide to Methods and Applications; Innis, M.A., Gelfand, D.H., Sninsky, J.J., White, T.J., Eds.; Academic Press: San Diego, CA, USA, 1990; pp. 315-322.

31. Vilgalys, R.; Hester, M. Rapid Genetic Identification and Mapping of Enzymatically Amplified Ribosomal DNA from Several Cryptococcus Species. J. Bacteriol. 1990, 172, 4238-4246. [CrossRef]

32. Kumar, S.; Stecher, G.; Tamura, K. MEGA7, Molecular Evolutionary Genetics Analysis Version 7.0 for Bigger Datasets. Mol. Biol. Evol. 2016, 33, 1870-1874. [CrossRef]

33. Nguyen, L.T.; Schmidt, H.A.; Von Haeseler, A.; Minh, B.Q. IQ-TREE: A Fast and Effective Stochastic Algorithm for Estimating Maximum-Likelihood Phylogenies. Mol. Biol. Evol. 2015, 32, 268-274. [CrossRef]

34. Kornerup, A.; Wanscher, J.H. Methuen Handbook of Colour, 3rd ed.; Eyre Methuen Ltd.: London, UK, 1978; pp. 1-252.

35. Velmurugan, P.; Kim, M.J.; Park, J.S.; Karthikeyan, K.; Lakshmanaperumalsamy, P.; Lee, K.J.; Park, Y.J.; Oh, B.T. Dyeing of Cotton Yarn with Five Water Soluble Fungal Pigments Obtained from Five Fungi. Fibers Polym. 2010, 11, 598-605. [CrossRef]

36. Morton, D.J.; Stroube, W.H. Antagonistic and Stimulatory Effects of Soil Microorganisms Upon Sclerotium rolfsii. Phytopathology $1955,45,417-420$

37. Rabha, A.J.; Naglot, A.; Sharma, G.D.; Gogoi, H.K.; Veer, V. In Vitro Evaluation of Antagonism of Endophytic Colletotrichum gloeosporioides Against Potent Fungal Pathogens of Camellia sinensis. Indian J. Microbiol. 2014, 54, 302-309. [CrossRef] [PubMed]

38. Jinesh, V.K.; Jaishree, V.; Badami, S.; Shyam, W. Comparative Evaluation of Antioxidant Properties of Edible and Non-Edible Leaves of Anethum graveolens Linn. Indian J. Nat. Prod. Resour. 2010, 1, 168-173.

39. Balouiri, M.; Sadiki, M.; Ibnsouda, S.K. Methods for In Vitro Evaluating Anti-microbial Activity: A Review. J. Pharm. Anal. 2016, 6, 71-79. [CrossRef] [PubMed]

40. Devi, S.; Karuppan, P. Reddish Brown Pigments from Alternaria alternata for Textile Dyeing and Printing. Indian J. Fibre Text. Res. 2015, 40, 315-319.

41. Janani, L.; Hillary, L.; Phillips, K. Mordanting Methods for Dyeing Cotton Fabrics with Dye from Albizia coriaria Plant Species. Int. J. Sci. Res. Publ. 2014, 4, 1-6. 